\title{
TECHNIQUES FOR ESTIMATING FLOOD-PEAK DISCHARGES OF RURAL, UNREGULATED STREAMS IN OHIO
}

By G. F. Koltun and John W. Roberts

U.S. GEOLOGICAL SURVEY

Water-Resources Investigations Report 89-4126

Final report on an

INVESTIGATION AND ANALYSIS OF FLOODS

FROM SMALL NORTHWESTERN, STRIP-MINED, AND FORESTED DRAINAGE BASINS IN OHIO

Prepared in cooperation with the

OHIO DEPARTMENT OF TRANSPORTATION

and the

U.S. DEPARTMENT OF TRANSPORTATION,

FEDERAL HIGHWAY ADMINISTRATION

The contents of this report reflect the views of the authors, who are responsible for the facts and the accuracy of the data presented herein. The contents do not necessarily reflect the official views or policies of the Ohio Department of Transportation or the Federal Highway Administration. This report does not constitute a standard, specification or regulation.

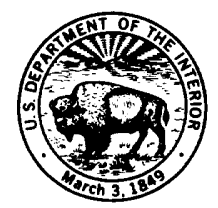

Columbus, Ohio 1990 
DEPARTMENT OF THE INTERIOR

MANUEL LUJAN, JR., Secretary

U.S. GEOLOGICAL SURVEY

Dallas Peck, Director

For additional information write to:

District Chief

U.S. Geological Survey

975 W. Third Avenue

Columbus, $\mathrm{OH}$ 43212-3192
Copies of this report can be purchased from:

U.S. Geological Survey Books and Open-File Reports Box 25425, Federal Center Building 810

Denver, CO 80225 


\title{
CONTENTS
}

\author{
Abstract 1 \\ Introduction 2 \\ Purpose and scope 2 \\ Approach 2 \\ Acknowledgments 3 \\ Techniques for estimating flood-peak discharges 3 \\ Estimating flood-peak discharge for a site on an ungaged stream 5 \\ Estimating flood-peak discharge for an ungaged site on a gaged stream 6 \\ Development of flood-frequency curves for streamflow-gaging stations 9 \\ Development of multiple-regression equations 10 \\ Selection of regressor variables $\mathbf{1 0}$ \\ Analysis of data on a statewide basis $\mathbf{1 1}$ \\ Analysis of data by selected regions 11 \\ Generalized least-squares regression 12 \\ Assessment of the multiple-regression equations 14 \\ Tests for collinearity 14 \\ Tests for constant residual variance 14 \\ Accuracy of the equations 15 \\ Sensitivity analysis 16 \\ Limitations of the equations 16 \\ Summary 19 \\ Selected references 21
}

\section{ILLUSTRATIONS}

Figure 1. Map showing locations of streamflow-gaging stations and region boundaries In pocket

2. Graph showing sensitivity of computed 2-year flood-peak discharges to change in regressor variables in the multiple-regression equations $\mathbf{1 7}$

3. Graph showing sensitivity of computed 100 -year flood-peak discharges to change in regressor variables in the multiple-regression equations

\section{TABLES}

Table 1. Equations for estimating flood-peak discharges of rural, unregulated streams in Ohio 4 


\section{TABLES--Continued}

Table 2. Statistics of selected basin characteristics for streamflow-gaging stations, by region 4

3. Flood-frequency data for streamflow-gaging stations 24

4. Selected basin characteristics of streamflow-gaging stations $\mathbf{5 0}$

5. $\hat{\rho}_{\mu \sigma}$ and $\hat{\Sigma}_{\max }$ values, by recurrence interval 65

6. Regions and $\mathrm{x}$-vectors 65

7. Variance-covariance $(U)$ matrices 66

\section{APPENDIXES}

Appendix A. Statistical techniques for determining confidence intervals and testing for extrapolation 58

Appendix B. Independent variables tested as potential regressor variables 67

\section{CONVERSION FACTORS AND ABBREVIATIONS}

For the convenience of readers who prefer metric (International System) units to the inchpound units in this report, values may be converted by use of the following factors:

Multiply inch-pound unit

inch (in.)

foot (ft)

mile (mi)

foot per mile $(\mathrm{ft} / \mathrm{mi})$

square mile $\left(\mathrm{mi}^{2}\right)$

cubic foot per second $\left(\mathrm{ft}^{3} / \mathrm{s}\right)$

acre-foot (acre-ft)
$\underline{B y}$

25.4

0.3048

1.609

0.1894

2.590

0.02832

0.001233
To obtain metric unit

millimeter (mm) meter $(\mathrm{m})$ kilometer $(\mathrm{km})$ meter per kilometer $(\mathrm{m} / \mathrm{km})$ square kilometer $\left(\mathrm{km}^{2}\right)$ cubic meter per second $\left(\mathrm{m}^{3} / \mathrm{s}\right)$ cubic hectometer $\left(\mathrm{hm}^{3}\right)$

Temperature is given in degrees Fahrenheit $\left({ }^{\circ} \mathrm{F}\right)$, which can be converted to degrees Celsius $\left({ }^{\circ} \mathrm{C}\right)$ by the following equation:

$$
{ }^{\circ} \mathrm{C}=\left[\left({ }^{\circ} \mathrm{F}\right)-32\right] / 1.8
$$

Sea level: In this report "sea level" refers to the National Geodetic Vertical Datum of 1929 (NGVD of 1929) - a geodetic datum derived from a general adjustment of the firstorder level nets of both the United States and Canada, formerly called "Sea Level Datum of 1929." 


\title{
TECHNIQUES FOR ESTIMATING FLOOD-PEAK DISCHARGES OF RURAL, UNREGULATED STREAMS IN OHIO
}

\author{
By G. F. Koltun and John W. Roberts
}

\begin{abstract}
Multiple-regression equations are presented for estimating flood-peak discharges having recurrence intervals of $2,5,10,25,50$, and 100 years at ungaged sites on rural, unregulated streams in Ohio. The average standard errors of prediction for the equations range from 33.4 percent to 41.4 percent.
\end{abstract}

Peak-discharge estimates determined by log-Pearson Type III analyses using data collected through the 1987 water year are reported for 275 streamflow-gaging stations. Ordinary least-squares multiple-regression techniques were used to divide the State into three regions and to identify a set of basin characteristics that help explain station-tostation variation in the log-Pearson estimates. Contributing drainage area, main-channel slope, and storage area were identified as suitable explanatory variables.

Generalized least-squares procedures, which include historical flow data and account for differences in the variance of flows at different gaging stations, spatial correlation among gaging station records, and variable lengths of station record, were used to estimate the regression parameters. Weighted peak-discharge estimates computed as a function of the log-Pearson Type III and regression estimates are reported for each station. A method is provided to adjust regression estimates for ungaged sites by use of weighted and regression estimates for a gaged site located on the same stream.

Limitations and shortcomings cited in an earlier report on the magnitude and frequency of floods in Ohio are addressed in this study. Geographic bias is no longer evident for the Maumee River basin of northwestern Ohio. No bias is found to be associated with the forested-area characteristic for the range used in the regression analysis $(0.0$ to 99.0 percent), nor is this characteristic significant in explaining peak discharges. Surfacemined area likewise is not significant in explaining peak discharges, and the regression equations are not biased when applied to basins having approximately 30 percent or less surface-mined area. Analyses of residuals indicate that the equations tend to overestimate flood-peak discharges for basins having approximately 30 percent or more surface-mined area. 


\section{INTRODUCTION}

Previous reports on the magnitude and frequency of floods in Ohio (Cross, 1946; Cross and Webber, 1959; Cross and Mayo, 1969; Webber and Bartlett, 1977) presented methods for estimating flood-peak discharges of rural, unregulated streams. Webber and Bartlett (1977) developed equations for estimating flood-peak discharges; however, they noted bias for basins that are heavily forested or are located within the Maumee River basin of northwestern Ohio. Furthermore, the 1977 equations are not applicable to basins that have substantial areas of surface mining or urbanization. Techniques for determining flood-flow frequency have been revised since the 1977 equations were developed (Interagency Advisory Committee on Water Data, 1982), and 12 additional years of flood-peak data (1976 through 1987) have been collected.

\section{Purpose and Scope}

The purpose of this report is to present techniques for estimating flood-peak discharges for rural, unregulated streams in Ohio. Better representation of flood-peak discharges is emphasized for basins that (1) are located within the Maumee River basin of northwestern Ohio, (2) have been subjected to surface mining and are either unreclaimed or have undergone various degrees of reclamation, or (3) are heavily forested. Multipleregression equations are given for estimating flood-peak discharges having recurrence intervals of $2,5,10,25,50$, and 100 years at ungaged sites. A method also is provided to adjust discharges estimated for an ungaged site by using weighted and regression flood-frequency estimates for a streamflow-gaging station located on the same stream. Computed flood-frequency discharge estimates are presented for each of the 275 streamflow-gaging stations used in this study. Examples of how to use the multiple-regression equations and the discharge-adjusting method also are provided. For the convenience of the user, the techniques and examples of their use immediately follow the introduction. Methods used to develop the regression equations and weighted estimates of peak discharge are presented in the latter sections of the report.

\section{$\underline{\text { Approach }}$}

Flood-frequency curves were developed for 275 streamflow-gaging stations on rural, unregulated streams following guidelines suggested by the Interagency Advisory Committee on Water Data (1982). Of these 275 stations, 249 are in Ohio (fig. 1, in pocket), thirteen are in Indiana, nine are in Pennsylvania, and four are in Michigan. All 275 streamflow-gaging stations had 10 or more years of recorded annual peak-discharge data.

The data base for this study included 166 continuous-record streamflow-gaging stations, 88 partial-record crest-stage streamflow-gaging stations, and 21 stations having 
both continuous and partial records. Thirty of the partial-record stations (fig. 1) were established for this study to provide better representation of flood-peak discharges on basins that (1) are located within the Maumee River basin of northwestern Ohio, (2) have been subjected to surface mining, or (3) are heavily forested. Flood-frequency curves were developed for each of the 30 partial-record crest-stage stations from 10 years of flood-peak discharge data collected from water years ${ }^{1} 1978$ through 1987. Basins substantially affected by urbanization were not included in the data base; however, Sherwood (1986) presents techniques for estimating flood-peak discharges, flood volumes, and hydrograph shapes for streams draining small (less than 4.10 square miles) urbanized basins in Ohio.

Ordinary and generalized least-squares multiple-regression techniques were used to develop equations that relate flood-peak discharges having recurrence intervals of 2,5, $10,25,50$, and 100 years to selected basin characteristics for the 275 streamflow-gaging stations.

\section{Acknowledgments}

This report was prepared in cooperation with the Ohio Department of Transportation and the U.S. Department of Transportation, Federal Highway Administration. Floodpeak discharge data from the network of 30 partial-record crest-stage stations were collected under this cooperative agreement. The remaining streamflow data used in this study have been collected under cooperative agreements with other Federal, State, and local agencies.

\section{TECHNIQUES FOR ESTIMATING FLOOD-PEAK DISCHARGES}

The following basin characteristics, determined from U.S. Geological Survey 7.5minute topographic quadrangle maps, are used in multiple-regression equations to estimate flood-peak discharges having recurrence intervals of 2, 5, 10,25, 50, and 100 years at ungaged sites on rural, unregulated streams in Ohio (table 1):

Contributing drainage area (CONTDA), in square miles; area measured in a horizontal plane that contributes surface runoff to a specified location on a stream. This area may be located inside or outside of the natural topographic divides of the basin.

${ }^{1}$ A water year is the 12-month period from October 1 through September 30 , and is designated by the calendar year in which it ends. 


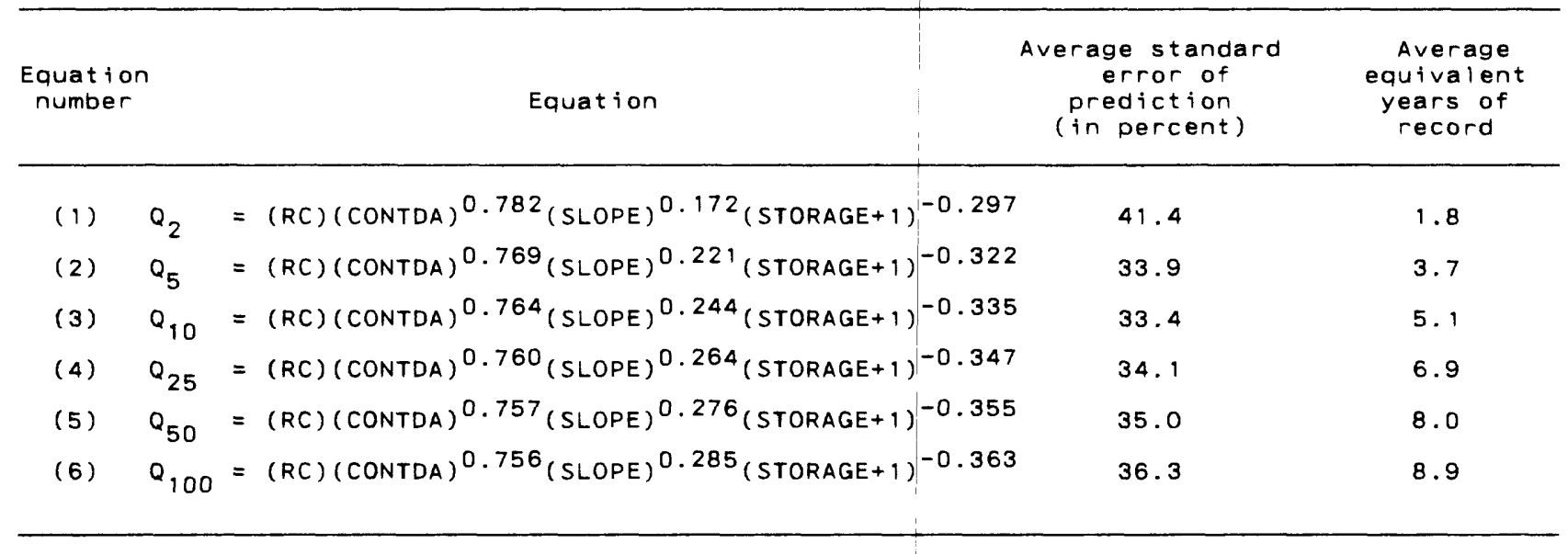

where $R C$ is the regression constant for a region from the following matrix:

$\begin{array}{ccccccc}\text { Region } & Q_{2} & Q_{5} & Q_{10} & Q_{25} & Q_{50} & Q_{100} \\ \text { A } & 56.1 & 84.5 & 104 & 129 & 148 & 167 \\ \text { B } & 40.2 & 58.4 & 69.3 & 82.2 & 91.2 & 99.7 \\ \text { C } & 93.5 & 133 & 159 & 191 & 214 & 236\end{array}$

CONTDA is the contributing drainage area (in square miles).

SLOPE is the main-channel slope (in feet per mile), and

STORAGE is the storage area (in percent).

Table 2.--Statistics of selected basin characteristics for streamflow-gaging stations, by region

[CONTDA, contributing drainage area; $f t / m i$, feet per mile; $\mathrm{mi}^{2}$, square miles]

\begin{tabular}{|c|c|c|c|c|}
\hline Region & Statistic & $\begin{array}{l}\text { CONTDA } \\
\left(m i^{2}\right)\end{array}$ & $\begin{array}{l}\text { SLOPE } \\
(\mathrm{ft} / \mathrm{mi})\end{array}$ & $\begin{array}{l}\text { STORAGE } \\
\text { (percent) }\end{array}$ \\
\hline A & $\begin{array}{l}\text { Maximum } \\
\text { Minimum } \\
\text { Mean } \\
\text { Median }\end{array}$ & $\begin{array}{c}7.422 \\
295 \\
64.012\end{array}$ & $\begin{array}{r}994 \\
1.4 \\
52.5 \\
12.6\end{array}$ & $\begin{array}{l}5.6 \\
0.0 \\
.5 \\
0.0\end{array}$ \\
\hline B & $\begin{array}{l}\text { Maximum } \\
\text { Minimum } \\
\text { Mean } \\
\text { Median }\end{array}$ & $\begin{array}{c}6.330 \\
353.040 \\
55.0\end{array}$ & $\begin{array}{r}500 \\
1.3 \\
28.3 \\
8.0\end{array}$ & $\begin{array}{r}13.0 \\
0.0 \\
1.0 \\
0.0\end{array}$ \\
\hline c & $\begin{array}{l}\text { Maximum } \\
\text { Minimum } \\
\text { Mean } \\
\text { Median }\end{array}$ & $\begin{array}{c}3.630 \\
330.260 \\
96.5\end{array}$ & $\begin{array}{r}145 \\
3.4 \\
30.8 \\
13.6\end{array}$ & $\begin{array}{l}1.6 \\
0.0 \\
.2 \\
0.0\end{array}$ \\
\hline
\end{tabular}


Main-channel slope (SLOPE), in feet per mile; computed as the difference in elevation at points 10 and 85 percent of the distance along the main channel from a specified location on the channel to the topographic divide, divided by the channel distance between the two points.

Storage area (STORAGE); the percentage of the contributing drainage area occupied by lakes, ponds, and swamps as explicitly shown on U.S. Geological Survey 7.5-minute topographic quadrangle maps.

The multiple-regression equations are applicable to each of three regions delineated on figure 1. The appropriate regression constant must be selected from the regression constant matrix (table 1) to estimate a flood-peak discharge for a specified recurrence interval at an ungaged site within a particular region.

Before using the equations, tests for extrapolation should be made by comparing each measured basin-characteristic value for the ungaged site to the ranges of basin-characteristic values in the regression data set for each region (table 2), or by following the more rigorous procedures outlined in Appendix A. Use of the regression equations is not recommended when a basin-characteristic value is outside the range.

It is suggested that the reader refer to the section "Assessment of the Multiple-Regression Equations" for further information on the accuracy, sensitivity, and limitations of the equations.

\section{Estimating Flood-Peak Discharge for a Site on an Ungaged Stream}

The technique for estimating flood-peak discharge for a site on an ungaged stream is illustrated in the following example. The 100-year flood-peak discharge is needed for a site on an ungaged stream in Butler County, Ohio. First, it is confirmed that the basin is rural and the stream is unregulated. Then, by locating the site on figure 1 (in pocket), the Region C multiple-regression equation for estimating 100-year flood-peak discharges is chosen (table 1, page 4):

$$
\mathrm{Q}_{100}=236(\mathrm{CONTDA})^{0.756}(\mathrm{SLOPE})^{0.285}(\mathrm{STORAGE}+1)^{-0.363} \text {. }
$$


Basin characteristics for the ungaged site are determined:

CONTDA $=0.290$ square miles

SLOPE $=93.0$ feet per mile

STORAGE $=0.0$ percent

These values are substituted into the Region $\mathrm{C}$ equation--

$$
\begin{aligned}
& Q_{100}=236(0.290)^{0.756}(93.0)^{0.285}(0.0+1)^{-0.363} \\
& Q_{100}=337 \text { cubic feet per second. }
\end{aligned}
$$

\section{Estimating Flood-Peak Discharge for an Ungaged Site on a Gaged Stream}

The technique for estimating flood-peak discharge for an ungaged site on a gaged stream is illustrated in the following example. The 25-year flood-peak discharge is needed for an ungaged site on the Licking River in Licking County, Ohio. This site is located upstream from the discontinued streamflow-gaging station, Licking River at Toboso, Ohio (03147000). First, it is confirmed that the basin is rural and the stream is unregulated. Then, by locating the ungaged site on figure 1 (in pocket), the Region $A$ multiple-regression equation for estimating 25 -year flood-peak discharges is chosen (table 1, page 4):

$$
\mathrm{Q}_{25}=129(\mathrm{CONTDA})^{0.760}(\mathrm{SLOPE})^{0.264}(\mathrm{STORAGE}+1)^{-0.347}
$$

Basin characteristics for the ungaged site are determined:

CONTDA $=537$ square miles

SLOPE $=10.7$ feet per mile

STORAGE $=0.6$ percent

These values are substituted into the Region A equation--

$$
\begin{aligned}
& \mathrm{Q}_{25}=129(537)^{0.760}(10.7)^{0.264}(0.6+1)^{-0.347} \\
& \mathrm{Q}_{25}=24,300 \text { cubic feet per second. }
\end{aligned}
$$


If the contributing drainage area of an ungaged site on a gaged stream is between 50 and 150 percent of the contributing drainage area of a gaged site on the same stream, then the following method of adjusting the estimated flood-peak discharge of the ungaged site is suggested:

$$
\begin{aligned}
& \mathrm{Q}_{\mathrm{t}, \mathrm{a} \text { (ungaged) }}=\mathrm{Q}_{\mathrm{t}, \mathrm{r} \text { (ungaged) }}\left[\mathrm{R}-\frac{2(\Delta \mathrm{CONTDA})(\mathrm{R}-1)}{\operatorname{CONTDA}_{\text {(gaged) }}}\right] \text {, } \\
& \text { where } \quad R=\frac{Q_{t, w \text { (gaged) }}}{Q_{t, r \text { (gaged) }}} \\
& \text { and } Q_{t, a \text { (ungaged) }} \text { is the adjusted flood-peak discharge estimate having a recurrence } \\
& \text { interval of } t \text { years for the ungaged site; } \\
& \mathrm{Q}_{\mathrm{t}, \mathrm{r} \text { (ungaged) }} \text { is the multiple-regression equation estimate of flood-peak dis- } \\
& \text { charge having a recurrence interval of } t \text { years for the ungaged } \\
& \text { site; } \\
& \mathrm{Q}_{\mathrm{t}, \mathrm{W} \text { (gaged) }} \text { is the weighted flood-peak discharge estimate having a recur- } \\
& \text { rence interval of } t \text { years for the gaged site, reported in table 3; } \\
& \mathrm{Q}_{\mathrm{t}, \mathrm{r} \text { (gaged) }} \text { is the multiple-regression equation estimate of flood-peak dis- } \\
& \text { charge having a recurrence interval of } t \text { years for the gaged } \\
& \text { site, reported in table 3; }
\end{aligned}
$$

$\triangle C O N T D A$ is the absolute value of the difference between the contributing drainage areas of the gaged site and the ungaged site; and
CONTDA $_{\text {(gaged) }}$ is the contributing drainage area of the gaged site, reported in table 4 (at back of report).

This method (1) adjusts the regression estimate for the ungaged site by the ratio $\mathbf{R}$ when the contributing drainage area of the ungaged site equals the contributing drainage area of the gaged site and (2) prorates the adjustment to one as the contributing drainage area of the ungaged site approaches either 50 percent or 150 percent of the contributing drainage area of the gaged site. 
The 537-square-mile drainage area for the ungaged site on the Licking River is between 50 and 150 percent of the 672-square-mile drainage area of the discontinued streamflow-gaging station, Licking River at Toboso, Ohio. Flood-peak discharges having recurrence intervals of 25 years are determined for both sites:

$\mathrm{Q}_{25, \mathrm{r} \text { (ungaged) }}=24,300$ cubic feet per second (as determined above)

$\mathrm{Q}_{25, \mathrm{w} \text { (gaged) }}=31,500$ cubic feet per second (table 3)

$\mathrm{Q}_{25, \mathrm{r} \text { (gaged) }}=129(\mathrm{CONTDA})^{0.760}(\mathrm{SLOPE})^{0.264}(\mathrm{STORAGE}+1)^{-0.347}$

(Region A equation from table 1)

where the basin characteristics for the gaged site (table 4) are

CONTDA $=672$ square miles;

SLOPE $=8.2$ feet per mile;

STORAGE $=0.8$ percent.

These values are substituted into the Region A equation:

$\mathrm{Q}_{25, \mathrm{r}(\mathrm{gaged})}=129(672)^{0.760}(8.2)^{0.264}(0.8+1)^{-0.347}$

$\mathrm{Q}_{25, \mathrm{r} \text { (gaged) }}=25,800$ cubic feet per second.

The absolute value of the difference between contributing drainage areas of the gaged site and the ungaged site ( $\triangle \mathrm{CONTDA}$ ) is computed as 135 square miles (672 square miles minus 537 square miles).

These discharge and contributing-drainage-area values are substituted into the equation for adjusting the estimated flood-peak discharge of the ungaged site--

$$
\begin{aligned}
& \mathrm{Q}_{25, \mathrm{a} \text { (ungaged) }}=24,300\left[\left(\frac{31,500}{25,800}\right)-\left(\frac{2(135)}{672}\right)\left(\frac{31,500}{25,800}-1\right)\right] \\
& \mathrm{Q}_{25, \mathrm{a} \text { (ungaged) }}=27,500 \text { cubic feet per second. }
\end{aligned}
$$




\section{DEVELOPMENT OF FLOOD-FREQUENCY CURVES FOR STREAMFLOW- GAGING STATIONS}

Flood-frequency curves were developed for 275 streamflow-gaging stations on rural, unregulated streams having at least 10 years of annual peak-discharge data. Interagency Advisory Committee on Water Data (1982) guideline's for determining floodflow frequency were followed.

A flood-frequency curve relates annual flood-peak magnitudes to annual exceedance probability. Annual exceedance probability can be expressed as the chance, in percent, of a given flood magnitude being exceeded in any one year. Recurrence interval, which is the reciprocal of the annual exceedance probability, is the average number of years between exceedances of a given flood magnitude. The occurrence of floods is considered to be random in time; therefore, no schedule of regularity is implied. The occurrence of a flood having a 100-year recurrence interval (1-percent annual exceedance probability) does not guarantee that a flood of equal or greater magnitude will not occur the following year or even the following week.

Observed annual flood-peak discharges were transformed to base 10 logarithms and fit to a Pearson Type III distribution. Low outliers were deleted, and adjustments were made for high outliers in light of historic flood information. Station skew was weighted with skew values from a generalized skew map (Interagency Advisory Committee on Water Data, 1982).

The flood-peak discharge at selected annual exceedance probabilities was computed by the equation:

$$
\log (\mathrm{Q})=\overline{\mathrm{X}}+\mathrm{KS},
$$

where $\overline{\mathrm{X}}$ is the mean of the logarithms of the observed annual flood-peak discharges;

$\mathrm{S}$ is the standard deviation of the logarithms of the observed annual flood-peak discharges; and

$\mathrm{K}$ is a function of the weighted skew coefficient and the selected annual exceedance probability.

These computed log-Pearson Type III flood-peak discharge estimates and their associated recurrence intervals $(2,5,10,25,50$, and 100 years) are presented in table 3 (at back of report). 


\section{DEVELOPMENT OF MULTIPLE-REGRESSION EQUATIONS}

Multiple-linear-regression techniques were used to relate selected basin characteristics (table 4, at back of report) to flood-peak discharges with 2-, 5-, 10-, 25-, 50-, and 100 -year recurrence intervals for the 275 streamflow-gaging stations. In multiple-linear regression, the dependent variable is assumed to be a linear function of two or more regressor variables. The general form of the multiple-regression equation used in this study is:

$$
\log \left(\mathrm{Q}_{\mathrm{t}}\right)=\log (\mathrm{C})+\mathrm{b}_{1} \log \left(\mathrm{X}_{1}\right)+\mathrm{b}_{2} \log \left(\mathrm{X}_{2}\right)+\ldots+\mathrm{b}_{\mathrm{p}} \log \left(\mathrm{X}_{\mathrm{p}}\right),
$$

where $Q_{1}$ is the estimated flood peak discharge, in cubic feet per second, having a $\mathrm{t}$-year recurrence interval, where t equals $2,5,10,25,50$, or 100 ;

$\mathrm{C}$ is a constant;

$b_{i}$ is the regression coefficient for the ith regressor variable $(i=1, \ldots, p)$;

$\mathrm{X}_{\mathrm{i}}$ is the $\mathrm{ith}$ regressor variable $(\mathrm{i}=1, \ldots, \mathrm{p})$; and

$\mathrm{p}$ is the total number of regressor variables in the equation.

For computational convenience, the above equation is presented in this report in the algebraically equivalent form:

$$
\mathrm{Q}_{\mathrm{t}}=\mathrm{C}\left(\mathrm{X}_{1}\right)^{\mathrm{b}_{1}}\left(\mathrm{X}_{2}\right)^{\mathrm{b}_{2}} \ldots\left(\mathrm{X}_{\mathrm{p}}\right)^{\mathrm{b}}
$$

\section{Selection of Regressor Variables}

Ordinary least-squares (OLS) multiple-regression analyses were performed using the SAS ${ }^{2}$ statistical procedures RSQUARE and STEPWISE (SAS Institute, 1982) to determine the optimum set of regressor variables. A variety of independent variables providing measures of different basin characteristics were explored as potential regressor variables. These independent variables listed here and explained in Appendix B included contributing drainage area, main-channel slope, main-channel length, mean basin elevation, basin elevation index, basin shape index, storage area, forested area, surface-mined

${ }^{2}$ Use of trade names in this report is for identification purposes only and does not constitute endorsement by the U.S. Geological Survey. 
area, mean annual precipitation, mean minimum January temperature, and 24-hour, 2-year rainfall. The final selection of regressor variables, however, was based on the following criteria:

1. The choice of regressor variables, as well as the signs and magnitudes of their associated regression coefficients, must be hydrologically plausible in the context of peak flows. This criterion takes precedence over all other criteria.

2. All regressor variables should be statistically significant at the 95-percent confidence level.

3. The choice of regressor variables, within the constraints of criteria 1 and 2 , should minimize the prediction error sum of squares (PRESS) and maximize the coefficent of determination $\left(R^{2}\right.$, a measure of the proportion of the variation in the dependent variable accounted for by the regression equation).

The variables selected using the criteria described above include (1) the contributing drainage area (CONTDA), (2) main-channel slope (SLOPE), and (3) storage area (STORAGE). Surface-mined area and forested area, two independent variables that were emphasized in this analysis, are not statistically significant in explaining peak discharges.

\section{Analysis of Data on a Statewide Basis}

Multiple-regression analyses were first performed on data from the 275 rural, unregulated streamflow-gaging stations in Ohio and adjacent states in an attempt to develop equations that would be applicable statewide. Plots of residuals, the differences between the log-Pearson Type III and regression estimates of peak discharge, for the statewide equations showed evidence of a geographic bias. Consequently, additional regression analyses were performed for selected regions in Ohio.

\section{Analysis of Data by Selected Regions}

The State was divided into regions using information on topography, drainage-basin boundaries, and areal trends of residuals for the statewide equations as guides. The locations of region boundaries were chosen so that no unregulated streams were crossed. The regionalization process served to compensate for the geographic bias observed in the statewide residual plots, which was not otherwise accounted for in the regression model. Geographic bias is not evident in the Maumee River basin of northwestern Ohio as had been previously observed by Webber and Bartlett (1977). 
Regionalization was accomplished in the regression model by means of a set of indicator variables. The indicator-variable method was used in lieu of separate regression analyses because it gives one estimate of the common error variance for the State and provides more residual degrees of freedom than would result from fitting separate regressions. The effect of the indicator variable is an adjustment in the intercept term for the logarithmic form of the regression equation. For the reader's convenience, the intercept term is combined with the constant and separate equations are reported for each region. Additional information on the use of indicator variables in multiple-regression analyses is provided by Montgomery and Peck (1982).

Ohio ultimately was divided into three regions using the information and method described above. These regions are shown on figure 1.

\section{Generalized Least-Squares Regression}

After an acceptable set of regressor variables were determined and the State was regionalized using OLS techniques, generalized least-squares (GLS) regressions were performed. Stedinger and Tasker (1985) found that the GLS procedure provides more accurate parameter (regression coefficient) estimates, better estimates of the accuracy with which the regression model's coefficients are being estimated, and almost unbiased estimates of the model error.

Unlike the OLS procedure, the GLS procedure takes into consideration the variance and spatial correlation structure of the streamflow characteristics and weights each observation accordingly (Tasker and others, 1986). In addition, the time-sampling error in the estimated $Q_{t}$ streamflow characteristic is accounted for in evaluating the accuracy of the regression equation. A third advantage to the GLS procedure is that historical peak-flow data can be considered in computing the time sampling error in $Q_{i}$.

The GLS analyses were performed using procedures incorporated into ANNIE/ WDM, a set of programs designed for the storage and interactive analysis of watershed and time-series data (Lumb and others, 1989). The equations developed by generalized least-squares regression are reported for the three regions in table 1.

Weighted estimates of the t-year peak discharges are reported in table 3 for the 275 streamflow-gaging stations. The weighted estimates are preferred for gaged sites over the log-Pearson Type III estimates or the regression estimates alone because they represent a weighted average of two independent estimates. The weighted estimates were 


$$
Q_{t, w}=10\left(\frac{\log \left(Q_{t, o}\right)(\omega)+\log \left(Q_{t, r}\right)\left(\omega_{e}\right)}{\omega+\omega_{e}}\right)
$$

where $Q_{t, 0}$ is the log-Pearson Type III estimate of the t-year peak discharge;

$Q_{t, r}$ is the regression estimate of the t-year peak discharge;

$\omega_{e}$ is the equivalent years of record for the regression estimate as defined by Hardison (1971); and

$\omega$ is Either the systematic record length, in years, if no historic peak discharge data are available for the site,

or

the effective record length, in years, as determined below, if historic peak-discharge data are available for the site-

$$
\omega=\omega_{s}+(A * D),
$$

where $\mathrm{A}=0.55-0.1^{*}(\ln (\mathrm{P} /(1-\mathrm{P})))$;

$$
\begin{aligned}
& P=1-\left(N_{p} /\left(\omega_{h}+\omega_{s}\right)\right) ; \\
& D=\min \left(200,\left(\omega_{h}-\omega_{s}\right)\right) ;
\end{aligned}
$$

$\mathrm{N}_{\mathrm{p}}$ is the number of historic peaks;

$\omega_{h}$ is the historic record length, in years; and

$\omega_{s}$ is the systematic record length, in years. 


\section{ASSESSMENT OF THE MULTIPLE-REGRESSION EQUATIONS}

\section{Tests for Collinearity}

Tests for collinearity, the condition where regressor variables exhibit near linear dependencies, were conducted using SAS. Severe collinearity can cause appreciable roundoff errors in the regression calculations. Moderate collinearity can have a destabilizing effect on parameter estimates, although estimates of the dependent variable may not be adversely affected.

A moderate level of collinearity (defined here as a condition number between 3 and 5 in combination with two or more regressors having variance-decomposition proportions greater than 0.5 ) is found between the variables CONTDA and SLOPE as determined by eigensystem analysis (SAS, 1982; Belsley and others, 1980). This moderate collinearity should not harm estimation if the conditions for estimation are confined to the regressor space within which the collinearity holds (Montgomery and Peck, 1982). The implication of this constraint is that extrapolation to combinations of regressor variables not represented in the development of the regression equation may lead to poor estimates of $Q_{i}$. Past experience with equations developed by Webber and Bartlett (1977), in which these variables also are present together, has demonstrated that satisfactory estimation, without extrapolation, can be done in spite of the collinearity.

\section{Tests for Constant Residual Variance}

Tests for constancy of residual variance were performed by plotting the regression residuals against the corresponding estimate of the dependent variable and by plotting the regression residuals against the corresponding values of each individual regressor variable by the SAS procedures REG and PLOT. The equations presented in this report have constant residual variance (characterized by a relatively uniform band of points around the line corresponding to the zero residual), which indicates that the residuals are not a function of regressor magnitude. More specifically, the residuals are not a function of contributing drainage area, main-channel slope, or storage area, thus, the regression equations are equally applicable for the full ranges of these characteristics used in the regression analysis (table 2).

Residuals also were plotted against independent variables not selected for use in the regression equations. These plots can reveal inadequacies in the regression equations caused by parametrical bias or the omission of an important explanatory variable. The residual variance associated with the variable representing forested area appears to be constant. This indicates that there is no bias associated with forested area for the range 
( 0.0 to 99.0 percent) used in the regression analysis. This lack of bias suggests that the regression equations are applicable to heavily forested basins (assuming the limitations discussed in the section "Limitations of the Equations" are met). The bias noted by Webber and Bartlett (1977) for heavily forested basins could have resulted from a limited or an unrepresentative sample. Residual variance is relatively constant for basins having approximately 30 percent or less surface-mined area. Consequently, unbiased estimates of peak discharge are obtained for those basins.

The equations tend to overestimate peak discharges for basins having approximately 30 percent or more surface-mined area. To illustrate this, average and median ratios of the log-Pearson Type III estimates to regression estimates for the 10 basins with greater than 30 percent surface-mined area are reported in the following table:

\begin{tabular}{rcc}
$\begin{array}{c}\text { Recurrence } \\
\text { interval } \\
\text { (years) }\end{array}$ & $\begin{array}{c}\text { Average ratio of } \\
\text { log-Pearson Type III } \\
\text { estimate to the } \\
\text { regression estimate }\end{array}$ & $\begin{array}{c}\text { Median ratio of } \\
\text { log-Pearson Type III } \\
\text { estimate to the } \\
\text { regression estimate }\end{array}$ \\
\hline & & \\
2 & 0.94 & 0.74 \\
5 & .87 & .62 \\
10 & .87 & .59 \\
25 & .89 & .58 \\
50 & .93 & .59 \\
100 & .97 & .60 \\
\hline
\end{tabular}

\section{Accuracy of the Equations}

Accuracy of the equations is assessed in terms of the average standard error of prediction and the average equivalent years of record. The average standard error of prediction, a measure of the average expected accuracy with which estimates of peak discharges can be made, was computed by taking the square root of the sum of the average model and sample error variances. The average standard error of prediction was converted to an average percent standard error of prediction by methods described by Hardison (1971). The average equivalent years of record represents an estimate of the number of years of actual stream-flow record required at a site to achieve an accuracy equivalent to the regional regression estimate. The average equivalent years of record is computed as part of the GLS analysis using the method described by Hardison (1971). 
The average standard error of prediction and average equivalent years of record are reported along with the regression equations in table 1.

The accuracy of individual discharge estimates can be assessed by computing individual estimates of the model and sample error variances. Techniques for computing these error variance estimates and confidence intervals are discussed in Appendix A.

\section{$\underline{\text { Sensitivity Analysis }}$}

Sensitivity analyses were conducted for the $\mathrm{Q}_{2}$ and $\mathrm{Q}_{100}$ regression equations. For a given equation, one regressor variable at a time was varied from its mean value in fixed increments while the remaining regressor variables were held constant at their mean values. In this way, the effects on the $\mathrm{Q}_{\mathrm{t}}$ discharge that are attributable to changes in each of the regressor variables were measured. Figures 2 and 3 show the percentage of change in the estimated $Q_{2}$ and $Q_{100}$ values, respectively, as a result of varying the regressor variables from +50 percent to -50 percent of their means. The dependent variable $\left(Q_{2}\right.$ or $\mathrm{Q}_{100}$ ) will be least affected by changes in regressor variables that plot closest to the horizontal dashed line. Conversely, the dependent variable is most sensitive to changes in variables that plot farthest from the horizontal dashed line. For example, the sensitivity plots for 2- and 100-year peak discharges show that the computation of $Q_{2}$ and $Q_{100}$ are most sensitive to changes in the contributing-drainage-area variable (CONTDA).

The basin-characteristics data used in the multiple-regression equations are generally computed or estimated from U.S. Geological Survey 7.5-minute topographic quadrangle maps. The sensitivity plots illustrate the relative magnitude of errors that could be introduced through inaccurate determination of basin characteristics. Although SLOPE and STORAGE are less sensitive than CONTDA, erroneous measures of these variables also could significantly effect the magnitude of the estimated flood-peak discharge.

Because the regional regression equations for a given recurrence interval differ only in their constants, all regions share the same sensitivity characteristics.

\section{Limitations of the Equations}

The multiple-regression equations for estimating flood-peak discharges should only be used for unregulated streams draining rural basins. In general, basins having usable storage of less than 103 acre-feet per square mile are considered to be unregulated; however, the flood-peak discharges for an ungaged site located directly below a large reservoir could be considered to be regulated regardless of the usable storage criterion (Benson, 1962). 


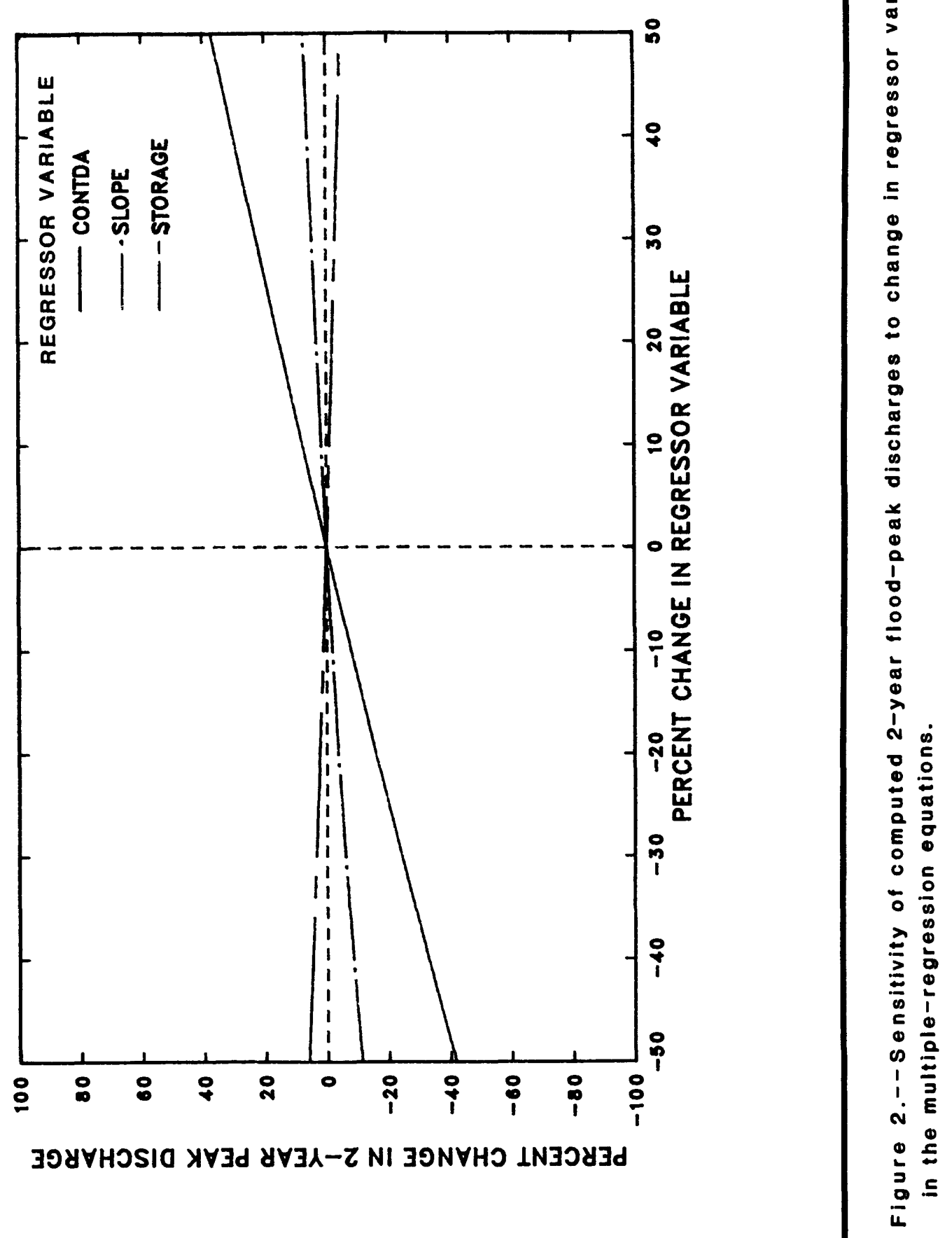




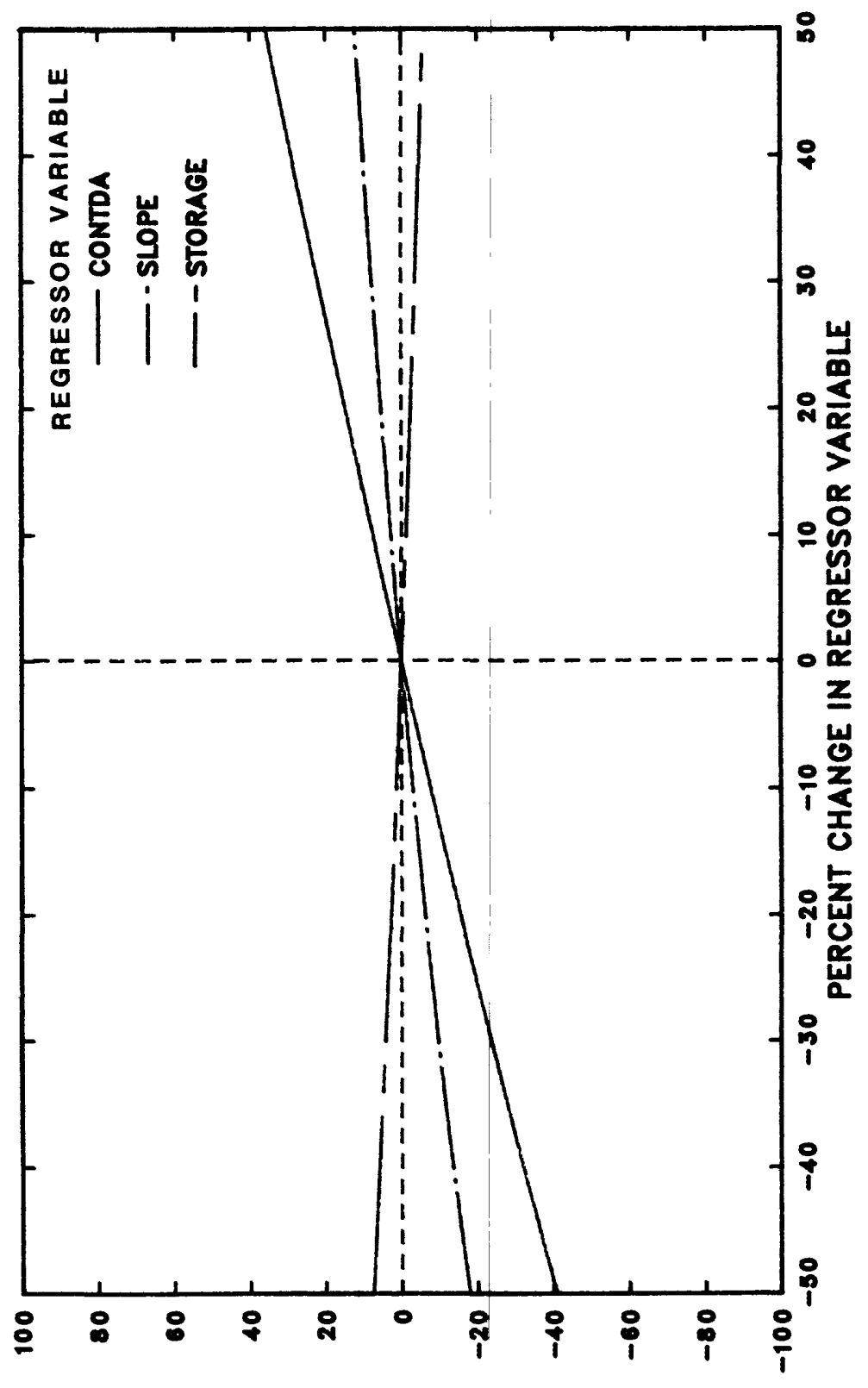

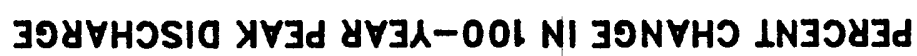


The applicability of the equations is unknown when the basin-characteristic values associated with an ungaged site are outside a space defined by the basin characteristics of the regression data set. This space, called a regressor variable hull (RVH), contains as many dimensions as there are regressor variables in the regression equation (Montgomery and Peck, 1982). If the point defined by the basin characteristics for the ungaged site lies within or on the boundary of the $\mathrm{RVH}$, then the estimation involves interpolation. If the point lies outside the $\mathrm{RVH}$, then the estimation would require extrapolation, which may lead to poor performance of the regression equation. The preferred method for testing for extrapolation involves matrix computations (discussed in Appendix A) that are somewhat unwieldy for routine use. An alternative method of testing for extrapolation, although less rigorous, involves comparing the individual basin characteristics of the ungaged site to the ranges of values observed in the original data for each region. Table 2 presents these ranges so that tests for extrapolation can be made. Use of the regression equations is not recommended when a basin characteristic value is outside the range.

The equations are applicable to basins having surface-mined areas; however, they should be used with caution for streams draining basins with approximately 30 percent or more surface-mined area. Tests for constant residual variance indicate a tendency to overestimate flood-peak discharges above this percentage.

\section{SUMMARY}

Flood frequency curves were developed for 275 streamflow-gaging stations on rural, unregulated streams in Ohio and adjacent states. Log-Pearson Type III estimates of flood-peak discharge having recurrence intervals of $2,5,10,25,50$, and 100 years are reported.

Ordinary least-squares multiple-regression techniques were used to divide the State into three regions and identify a set of basin characteristics that help explain station-tostation variation in flood-peak discharge. Contributing drainage area (CONTDA), mainchannel slope (SLOPE), and storage area (STORAGE) were identified as suitable explanatory variables.

Equations were developed for estimating flood-peak discharges at ungaged sites on rural, unregulated streams in Ohio. Generalized least-squares (GLS) regression analyses were used to estimate the regression parameters. The average standard errors of prediction for the equations range from 33.4 percent to 41.4 percent. Guidelines for use of the equations are presented along with examples. 
Weighted estimates of the t-year peak discharges were computed for each gaging station in the GLS analysis from the log-Pearson Type III and regression estimates. These weighted estimates are reported along with the regression estimates. A method is provided to adjust regression estimates for ungaged sites as a function of contributing drainage area and the weighted and regression estimates for a gaged site located on the same stream.

Limitations and shortcomings noted by Webber and Bartlett (1977) in their report on the magnitude and frequency of floods in Ohio are addressed in this study. Thirty partialrecord crest-stage streamflow-gaging stations were established specifically to provide better representation of flood-peak discharges on basins that (1) are located within the Maumee River basin of northwestern Ohio, (2) have been subjected to surface mining and are either unreclaimed or have undergone various degrees of reclamation, or (3) are heavily forested. Geographic bias is no longer evident for the Maumee River basin of northwestern Ohio as a result of additional streamflow-gaging stations, 12 additional years of flood-peak data, and (or) regionalization. No bias is found to be associated with the forested-area characteristic for the range used in the regression analysis $(0.0$ to 99.0 percent), nor is this characteristic significant in explaining peak discharges. Surfacemined area likewise is not significant in explaining peak discharges, and the regression equations are not biased when applied to basins having approximately 30 percent or less surface-mined area. Analyses of residuals indicate that the equations tend to overestimate flood-peak discharges for basins having approximately 30 percent or more surfacemined area. Therefore, the regression equations presented in this report are applicable to basins that are heavily forested and to basins that have been subjected to surface mining; however, potential bias associated with basins having 30 percent or more surface-mined area should be considered when making flood-peak discharge estimates. 


\section{SELECTED REFERENCES}

Belsley, D.A., Kuh, E., and Welsch, R.E., 1980, Regression diagnostics: New York, Wiley, 292 p.

Benson, M.A., 1962, Factors influencing the occurrence of floods in a humid region of diverse terrain: U.S. Geological Survey Water-Supply Paper 1580-B, 64 p.

Cross, W.P., 1946, Floods in Ohio-Magnitude and frequency: Ohio Water Resources Board Bulletin 7, 154 p.

Cross, W.P., and Mayo, R.I., 1969, Floods in Ohio, magnitude and frequency-A supplement to Bulletin 32: Ohio Department of Natural Resources, Division of Water Bulletin 43, 230 p.

Cross, W.P., and Webber, E.E., 1959, Floods in Ohio, magnitude and frequency: Ohio Department of Natural Resources, Division of Water Bulletin 32, $325 \mathrm{p}$.

Curtis, W.R., 1979, Surface mining and the hydrologic balance: American Mining Congress Journal, v. 65 , no. 7,6 p.

Flippo, H.N., Jr., 1977, Floods in Pennsylvania: Pennsylvania Department of Environmental Resources, Water Resources Bulletin no. 13, 59 p.

Glatfelter, D.R., 1984, Techniques for estimating magnitude and frequency of floods on streams in Indiana: U.S. Geological Survey Water-Resources Investigations Report 84-4134, 110 p.

Hardison, C.H., 1971, Prediction error of regression estimates of streamflow characteristics at ungaged sites: U.S. Geological Survey Professional Paper 750-C, p. C228C236.

Holtschlag, D.J., and Croskey, H.M., 1984, Statistical models for estimating flow characteristics of Michigan streams: U.S. Geological Survey Water-Resources Investigations Report 84-4207, 80 p.

Interagency Advisory Committee on Water Data, 1982, Guidelines for determining flood flow frequency-Bulletin 17B of the Hydrology Subcommittee: U.S. Geological Survey, Office of Water Data Coordination, $183 \mathrm{p}$.

Kolva, J.R., 1985, Preliminary evaluation of magnitude and frequency of floods in selected small drainage basins in Ohio: U.S. Geological Survey Open-File Report $85-194,30 \mathrm{p}$. 
Lumb, A.M., Kittle, J.L., Jr., and Flynn, K.M., 1989, Users manual for ANNIE-a computer program for interactive hydrologic analyses and data management: U.S. Geological Survey Water Resources Investigation 89-4080, 251 p.

Montgomery, D.C., and Peck, E.A., 1982, Introduction to linear regression analysis: New York, Wiley, $504 \mathrm{p}$.

Ohio Division of Water, 1962, Hydrologic atlas of average annual precipitation, temperature, streamflow, and water loss in Ohio: Ohio Department of Natural Resources, Ohio Water Plan Inventory Report 13, 4 p.

SAS Institute Inc., 1982, SAS User's Guide-Statistics, 1982 edition: Cary, N.C., SAS Institute, $584 \mathrm{p}$.

Sherwood, J.M., 1986, Estimating peak discharges, flood volumes, and hydrograph shapes of small ungaged site urban streams in Ohio: U.S. Geological Survey WaterResources Investigations Report 86-4197, 52 p.

Stedinger, J.R., and Tasker, G.D., 1985, Regional hydrologic analysis 1. Ordinary, weighted, and generalized least squares compared: Water Resources Research, v. 21, no. 9, p. 1421-1432.

Tasker, G.D., Eychaner, J.H., and Stedinger, J. R., 1986, Application of generalized least squares in regional hydrologic regression analysis, in Subitzky, Seymour (ed.), Selected Papers in the Hydrologic Sciences 1986: U.S. Geological Survey Water Supply Paper 2310, p. 107-115.

U.S. Department of Commerce, 1959, Climates of the States, Ohio: Weather Bureau, Climatography of the United States, no. 60-33,20 p. 1961, Rainfall frequency atlas of the United States: Weather Bureau Technical Paper no. 40, 115 p.

Webber, E.E., and Bartlett, W.P., Jr., 1977, Floods in Ohio, magnitude and frequency: Ohio Department of Natural Resources, Division of Water Bulletin 45, $74 \mathrm{p}$.

Wetzel, K.L., and Bettandorff, J.M., 1986, Techniques for estimating streamflow characteristics in the eastern and interior coal Provinces of the United States: U.S. Geological Survey Water-Supply Paper 2276, 80 p. 
DATA TABLES 


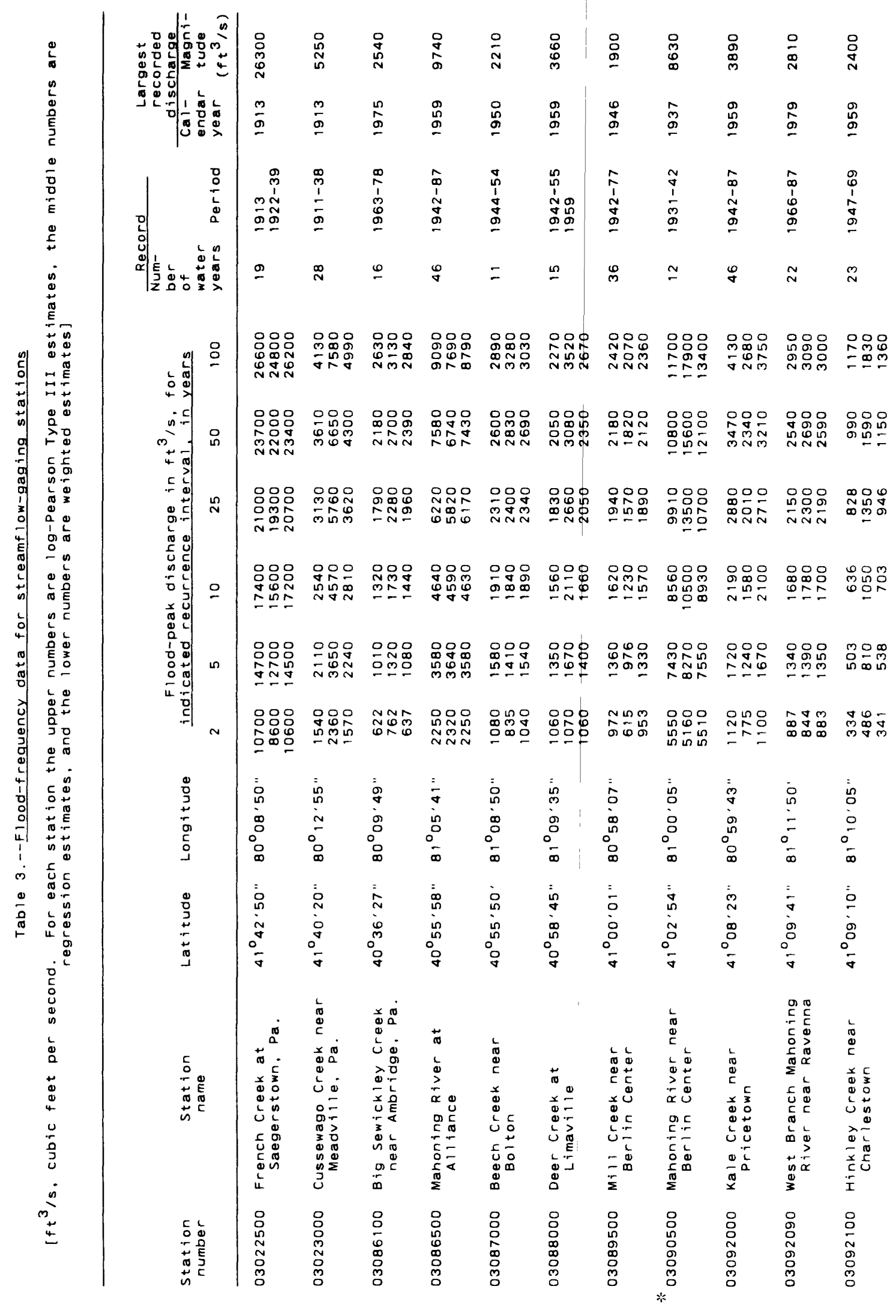




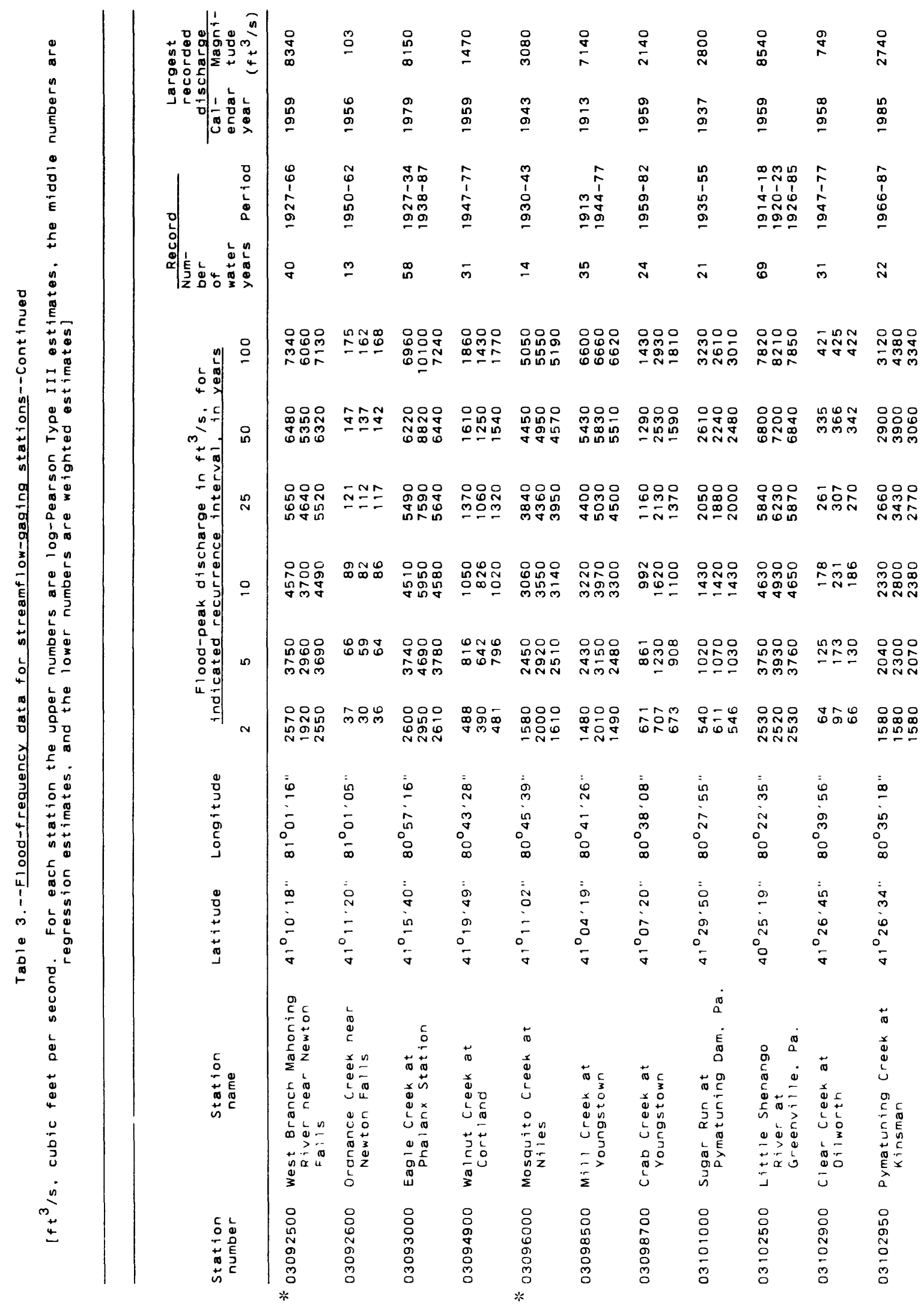




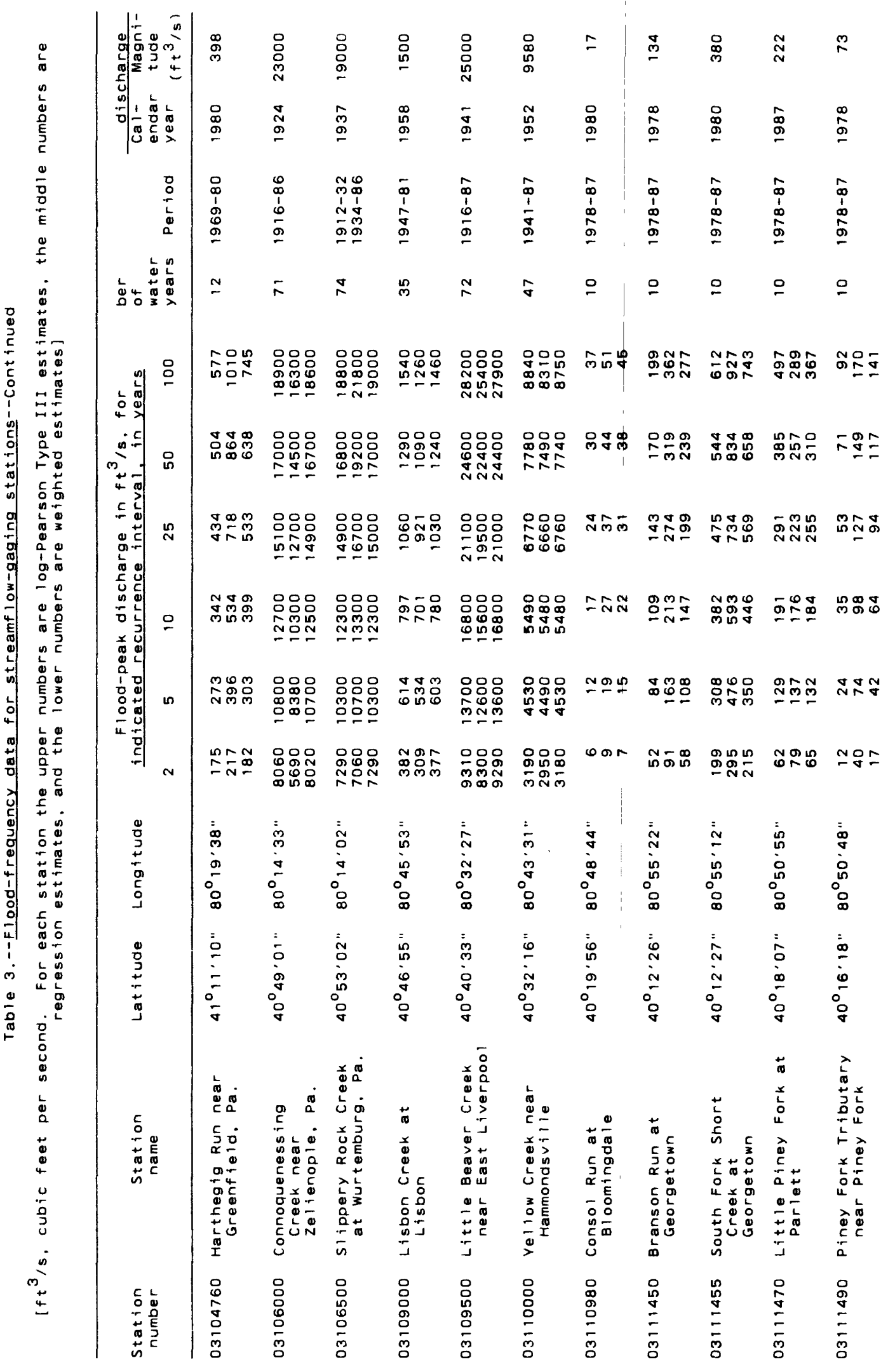




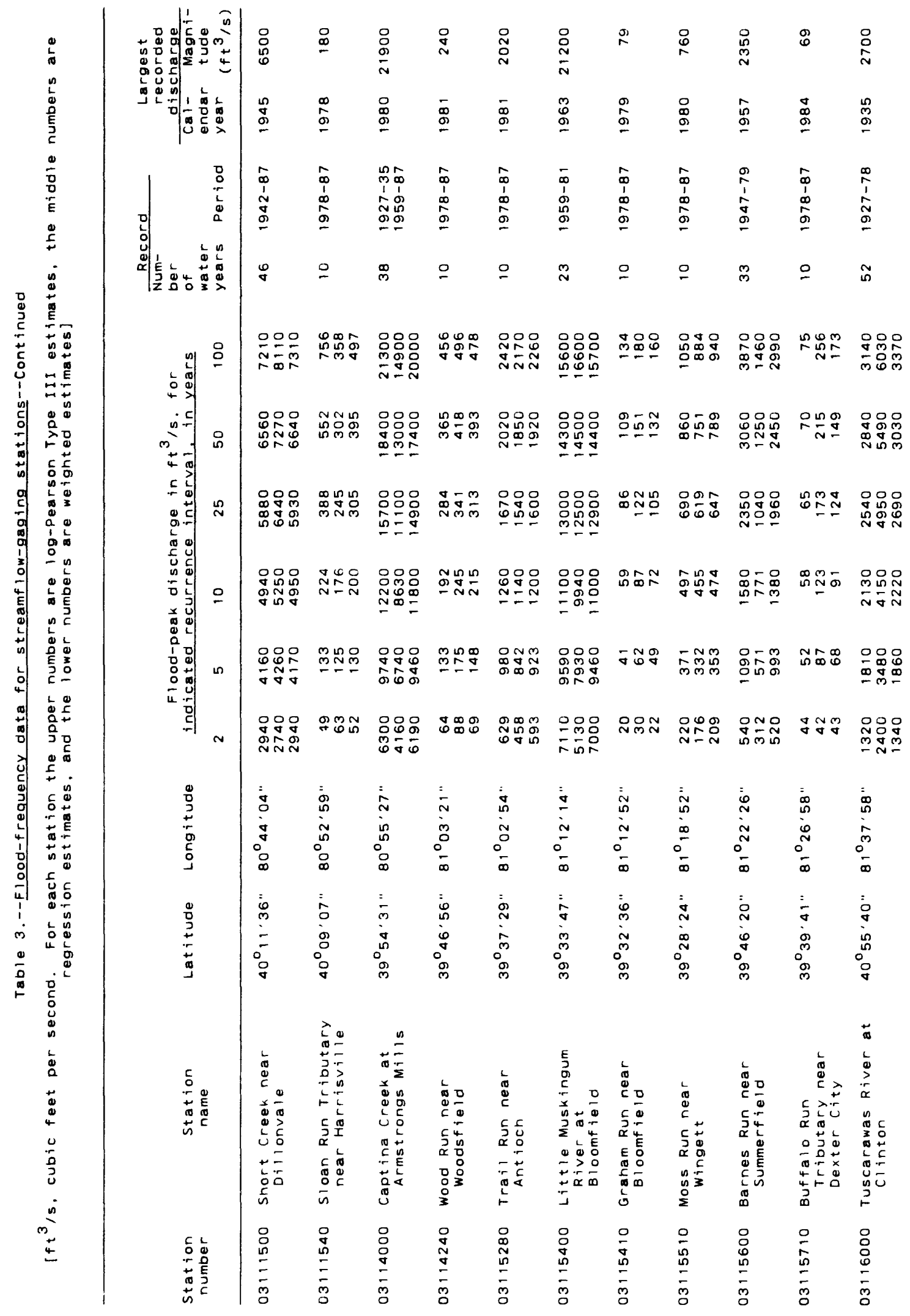




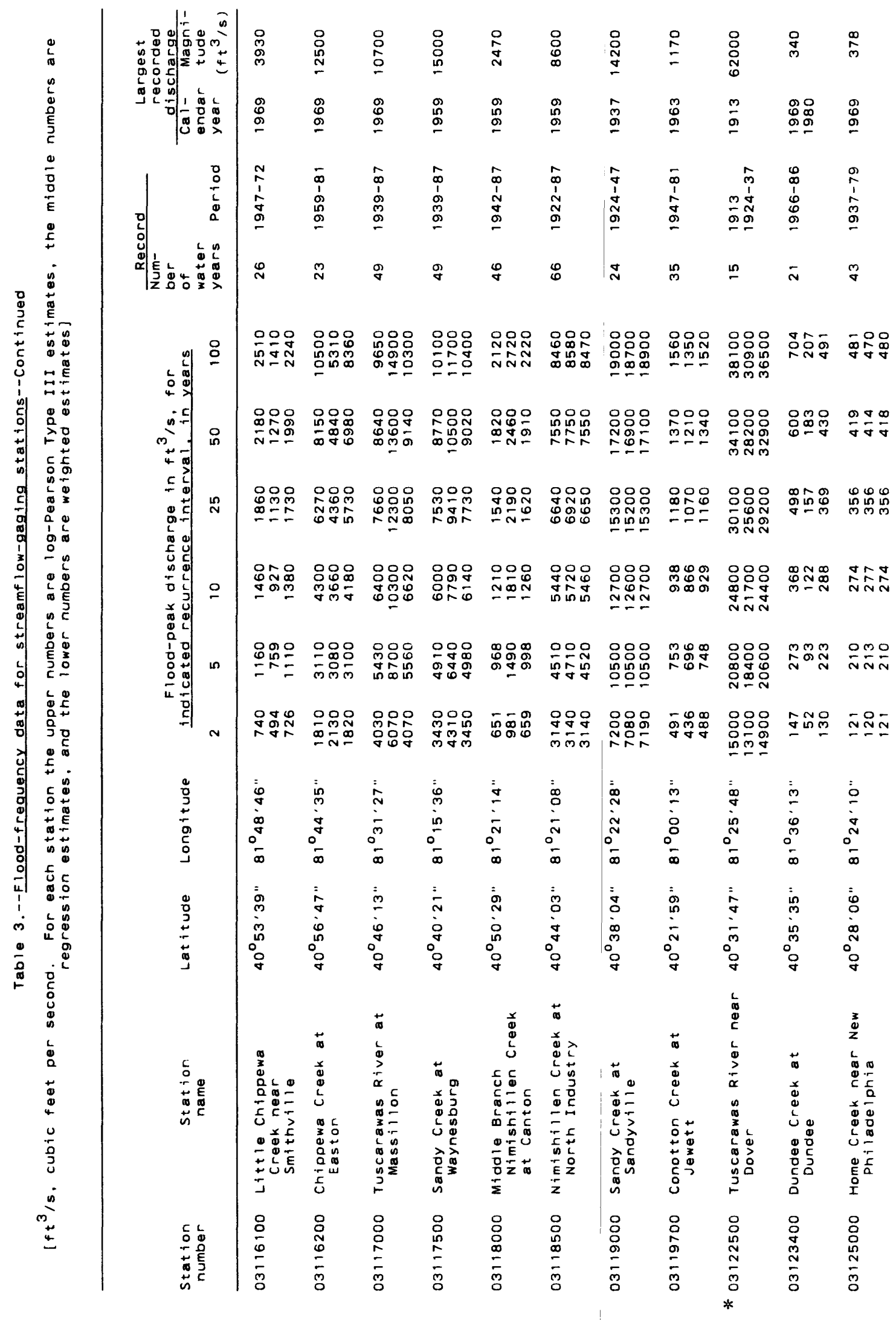




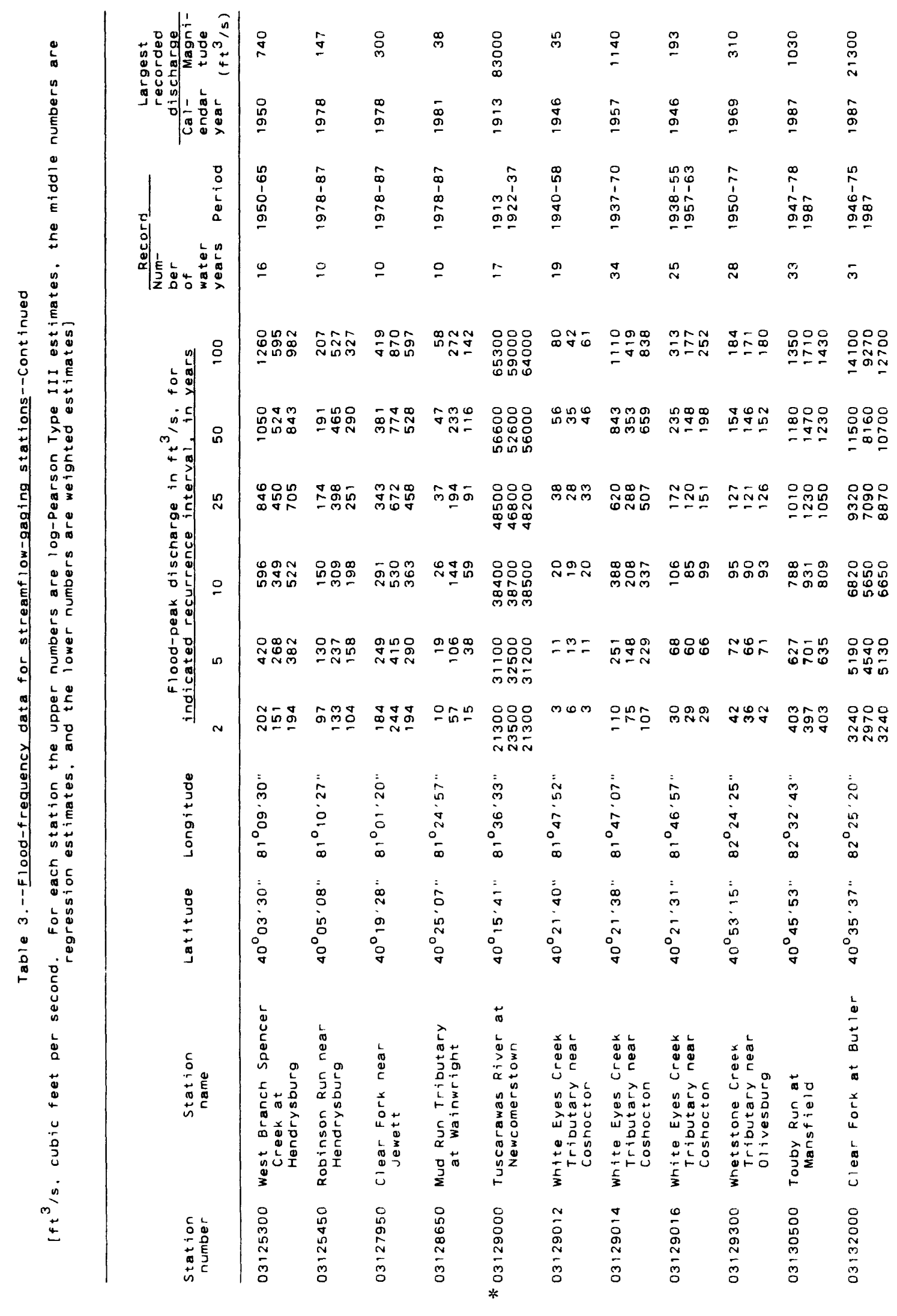




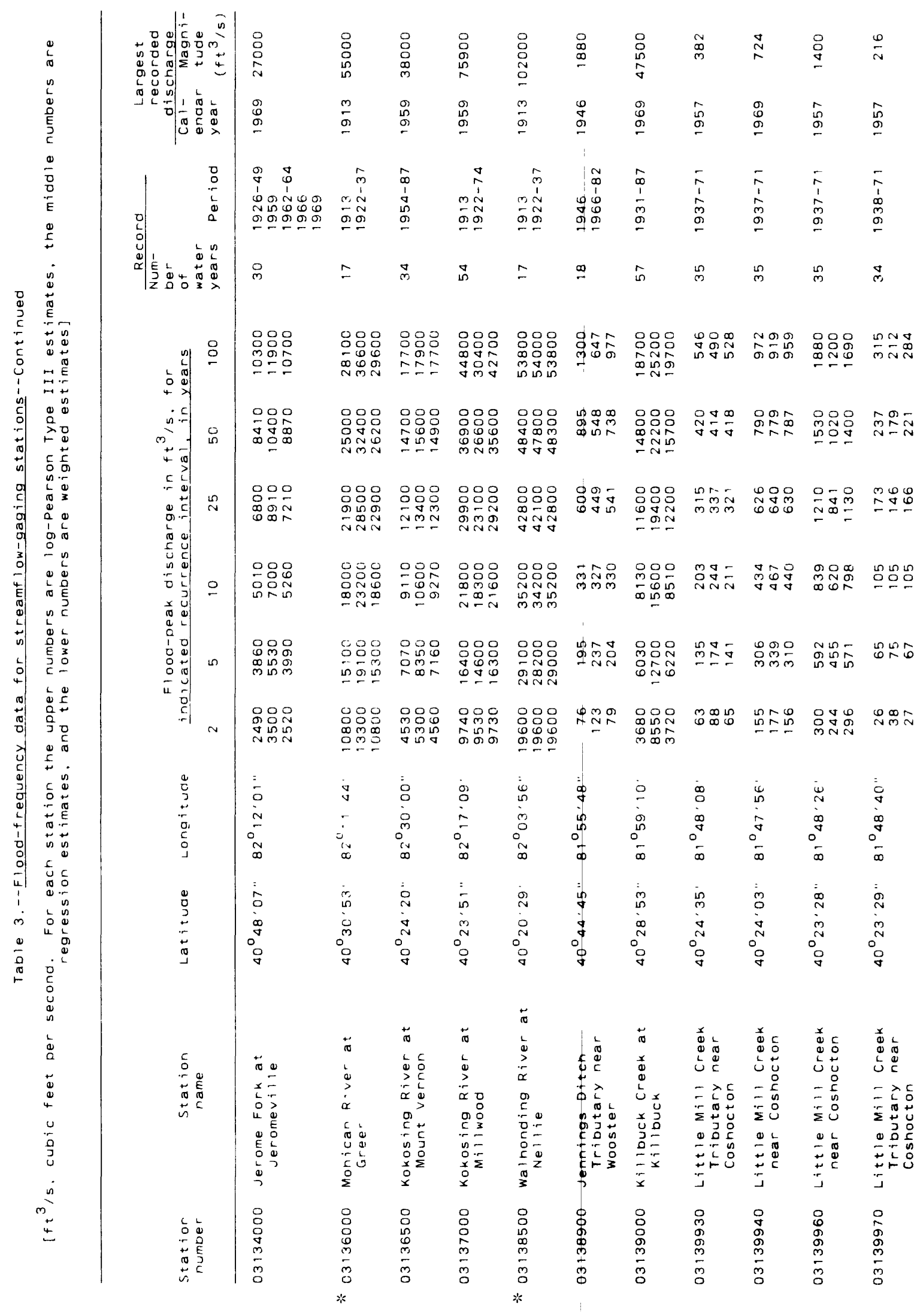




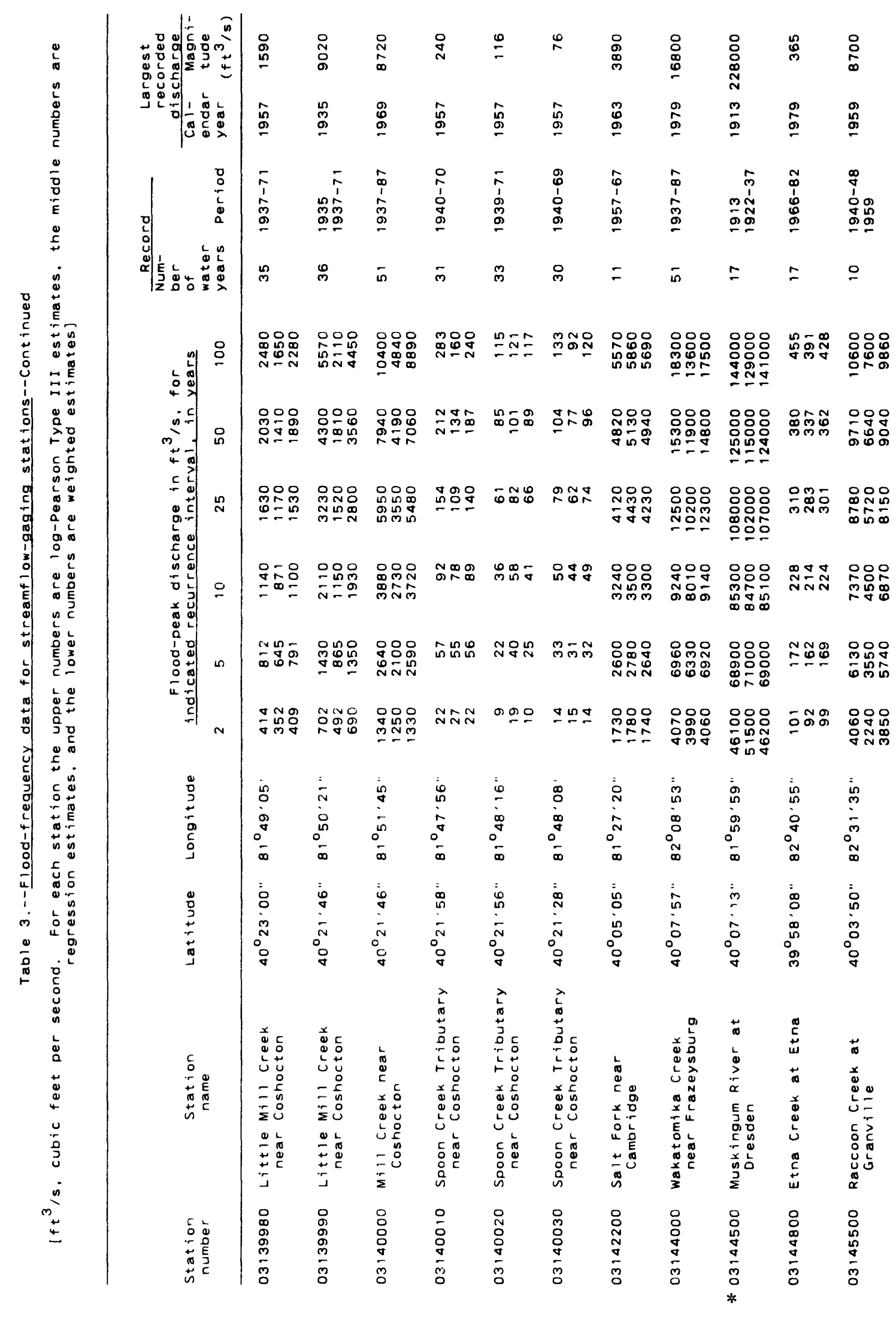




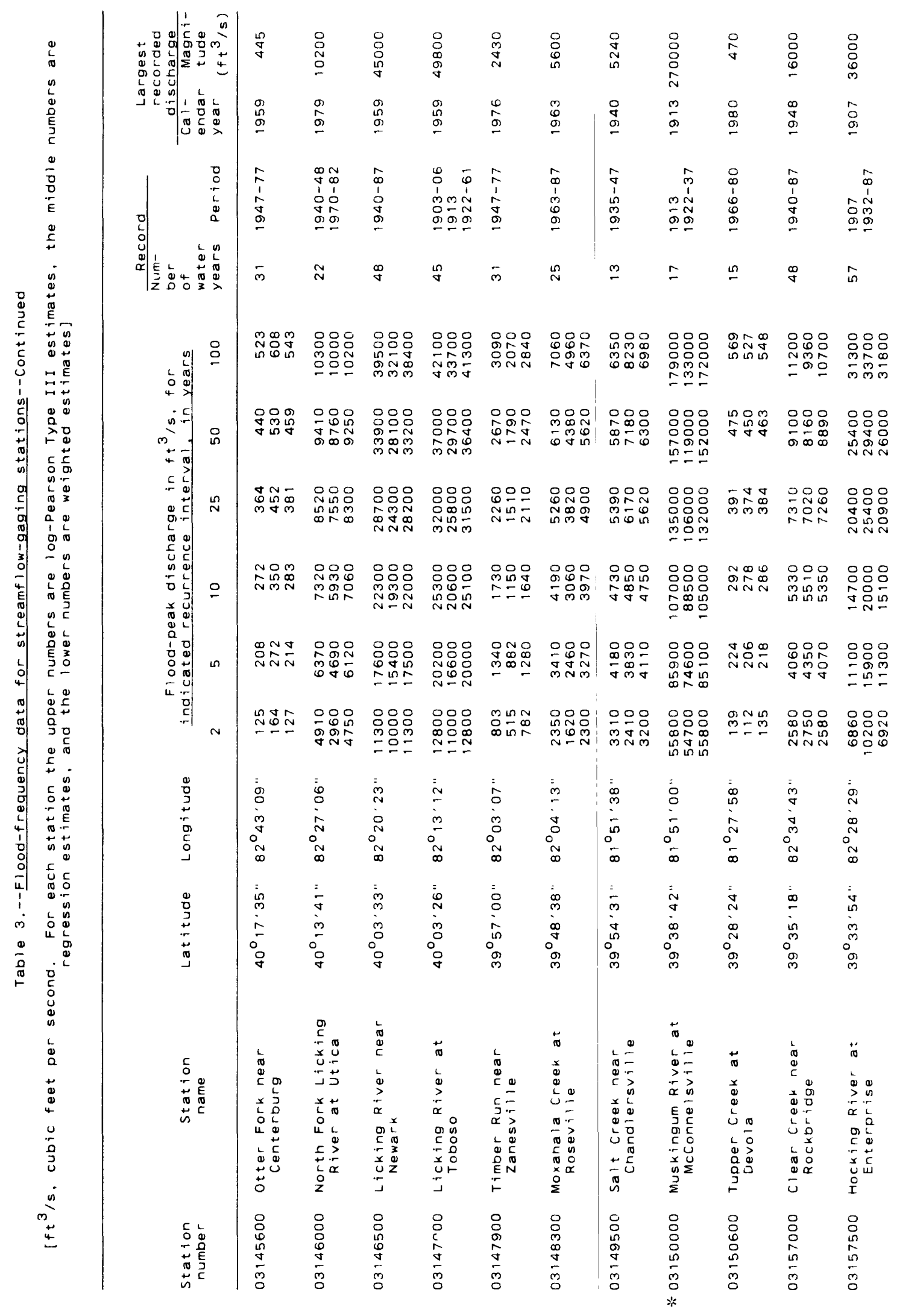




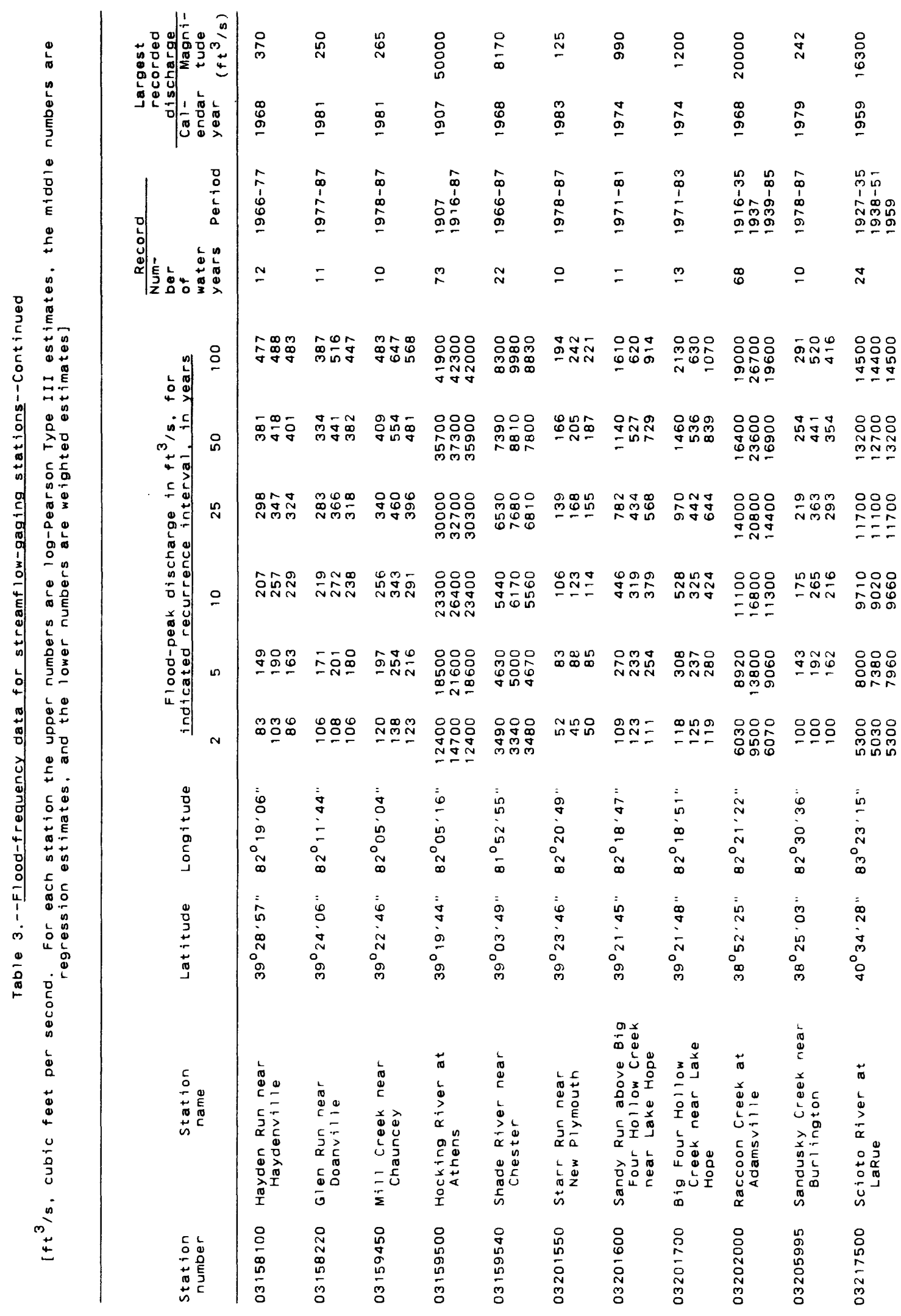




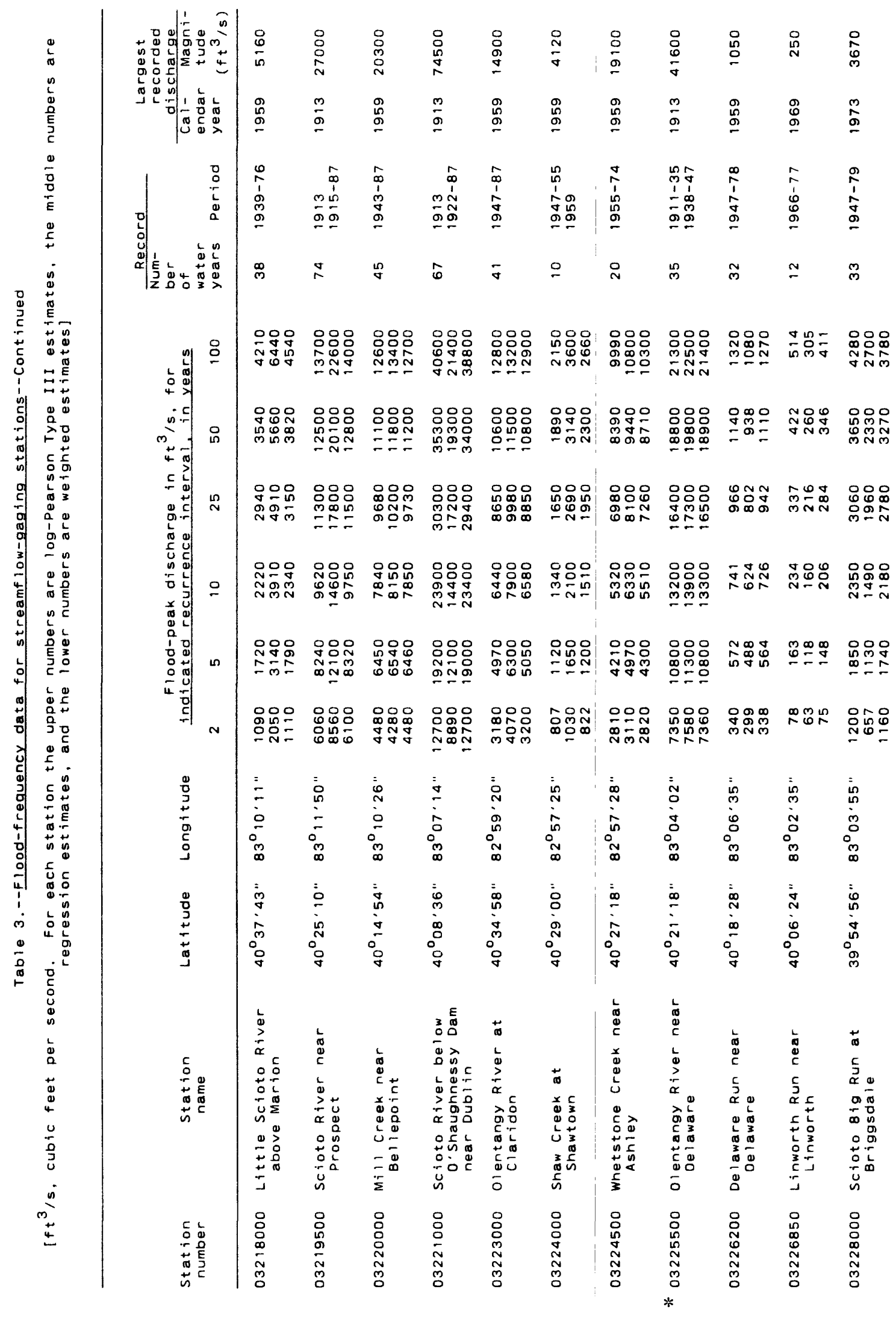




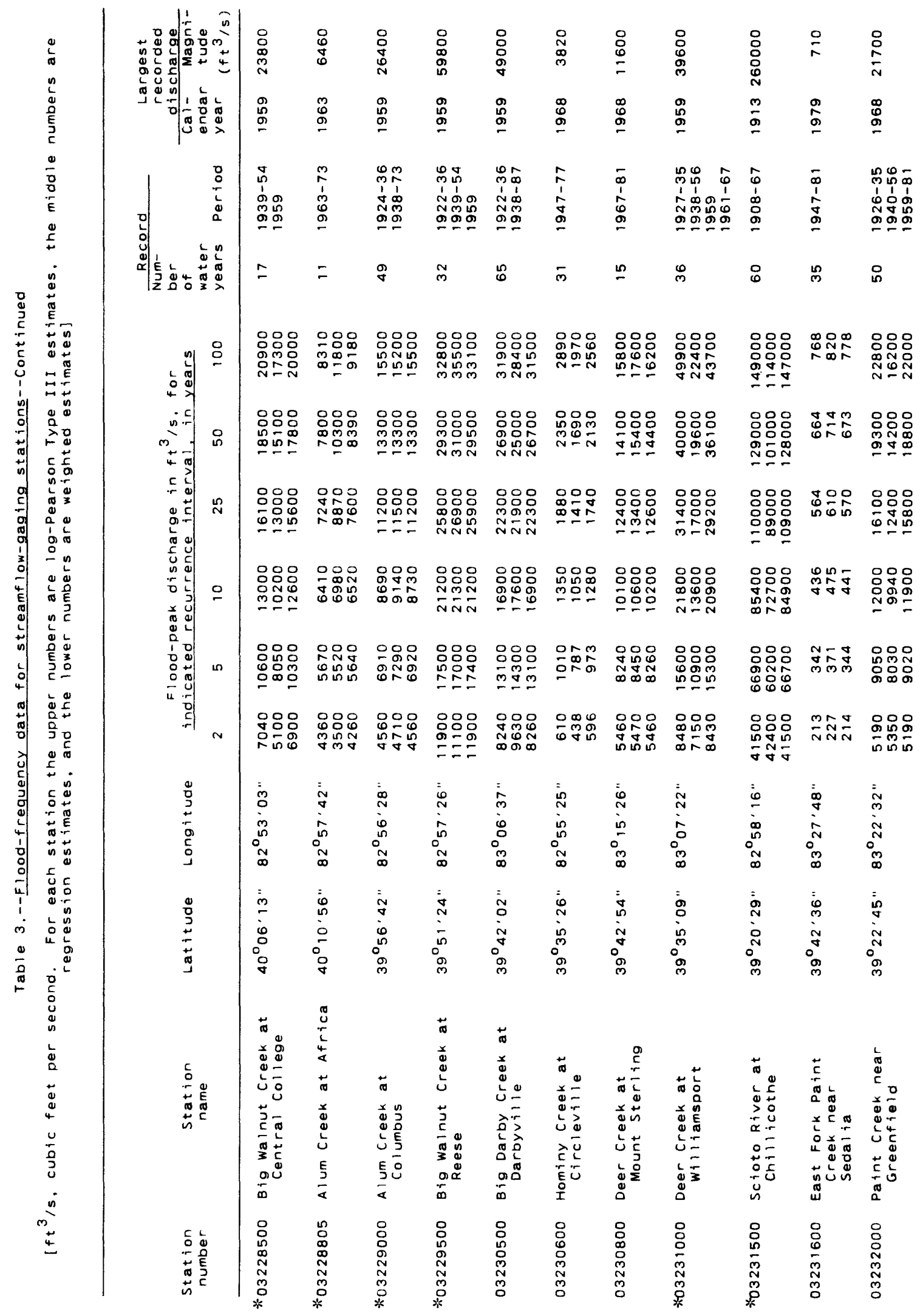




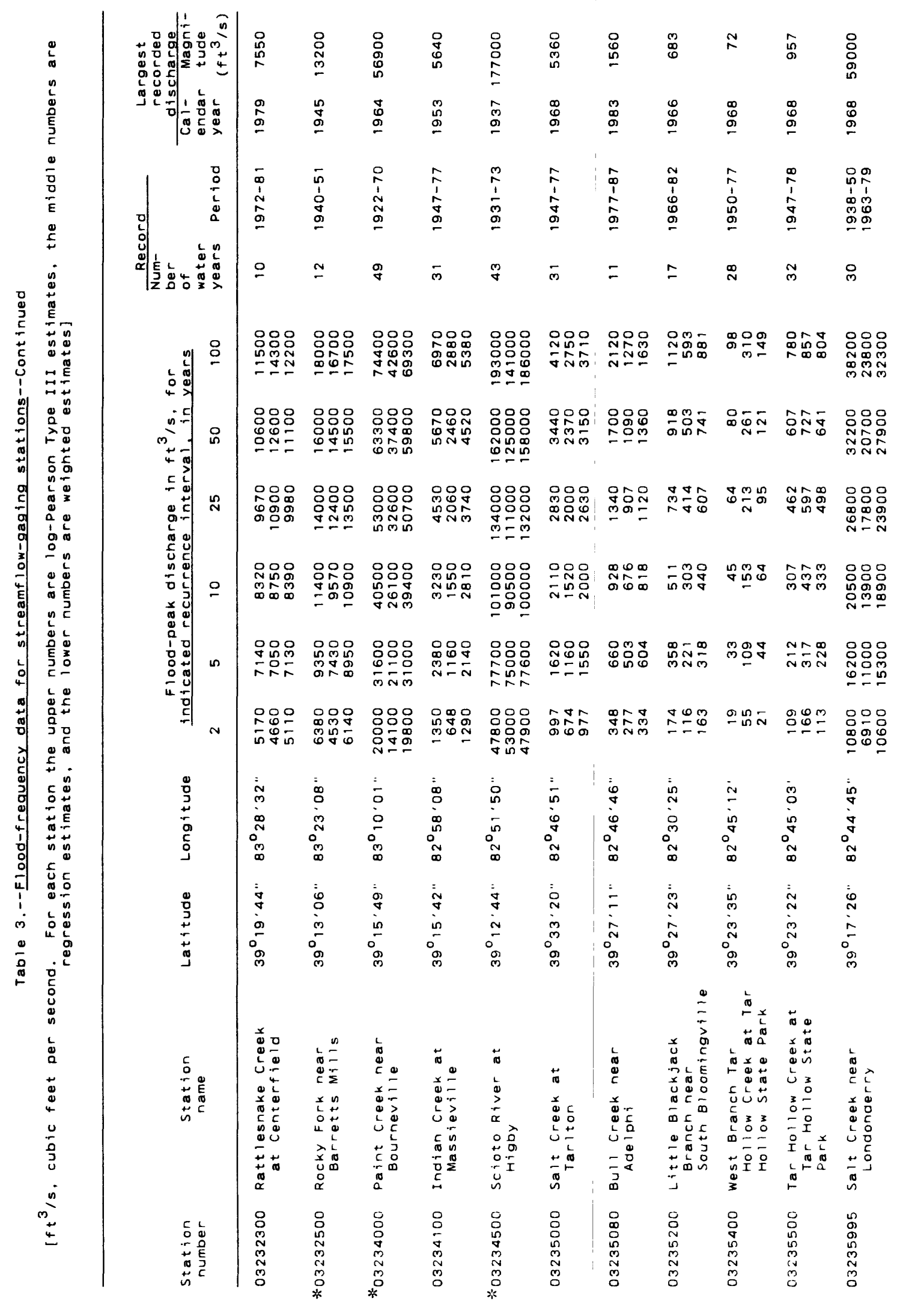




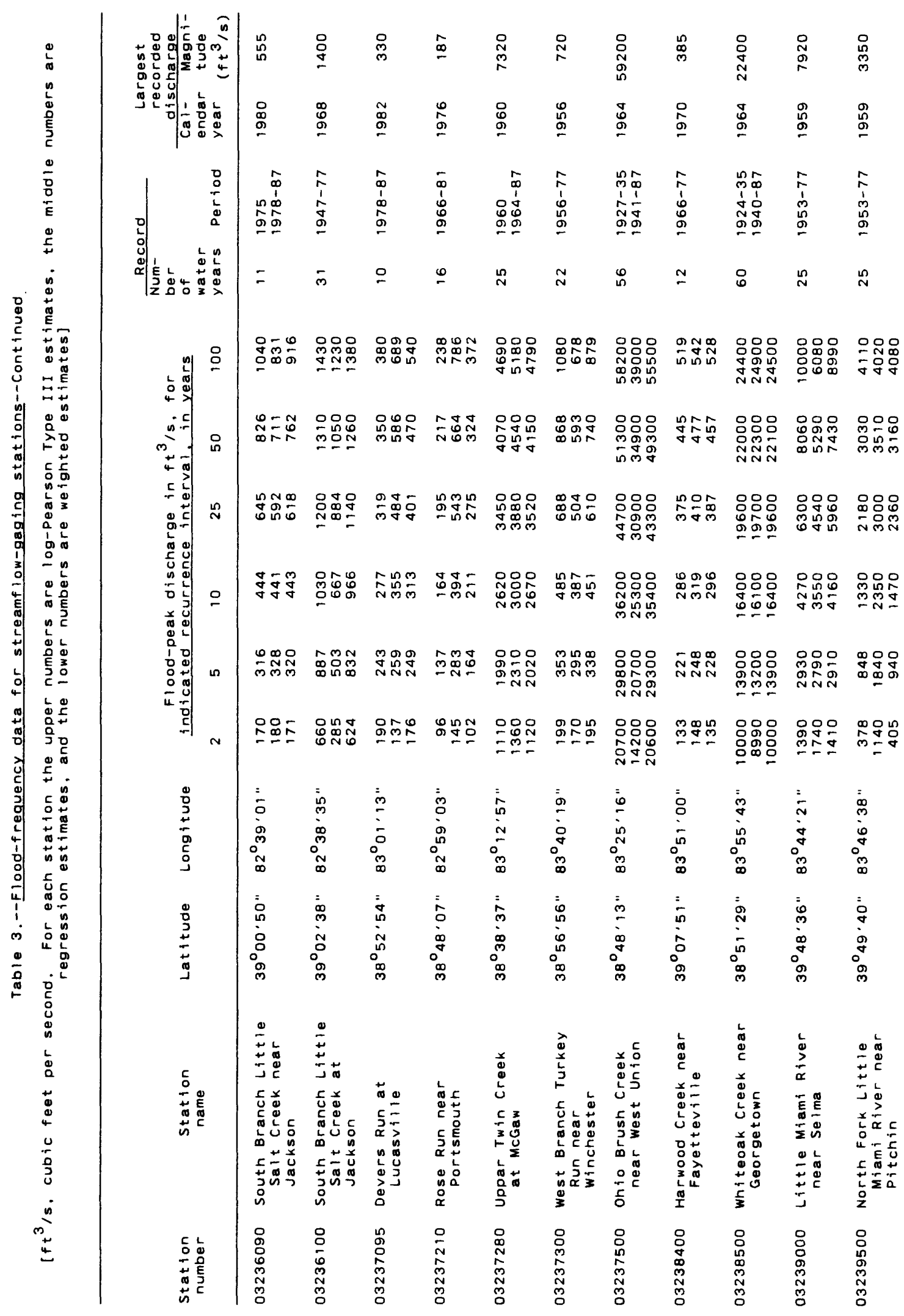




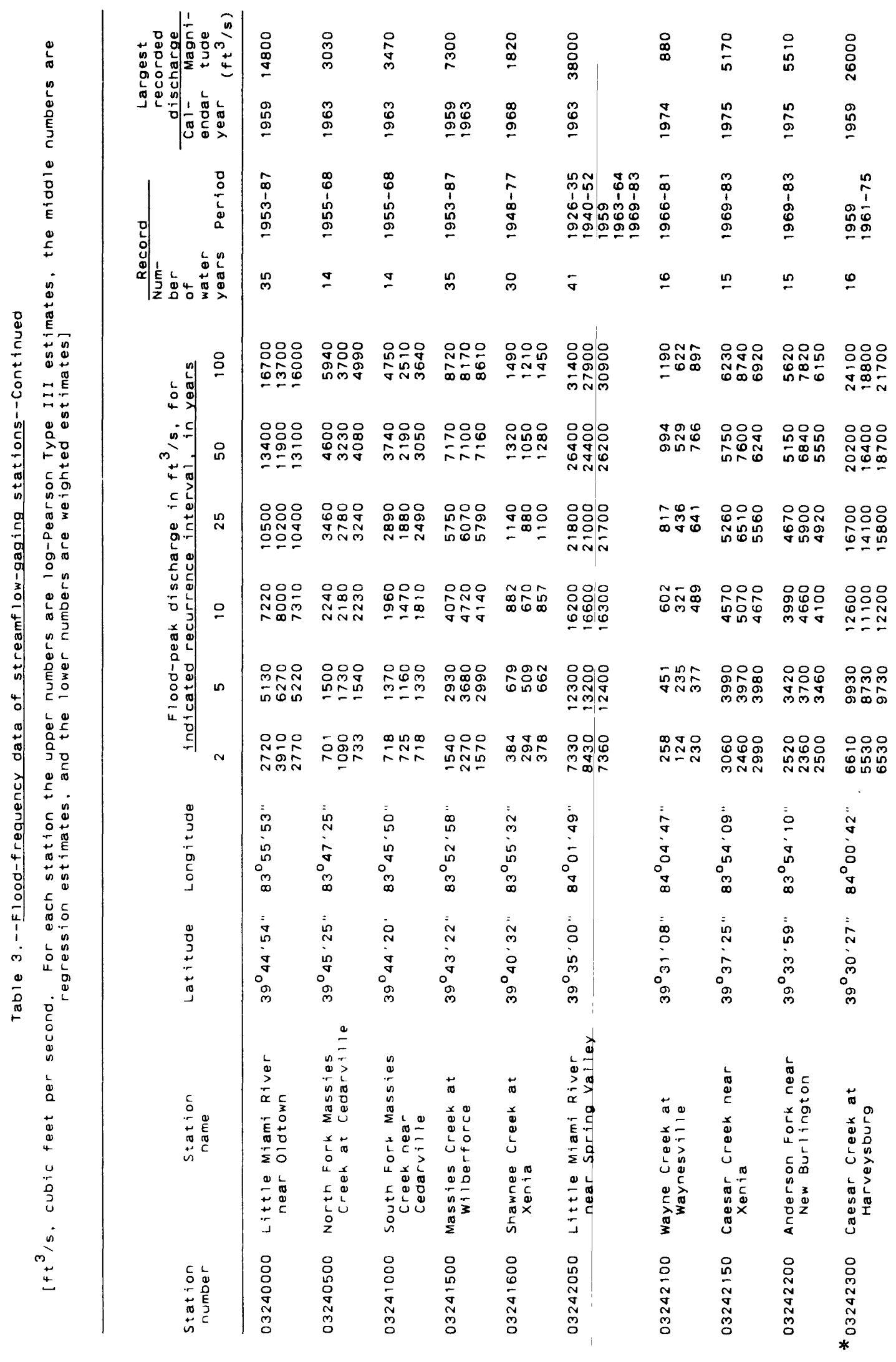




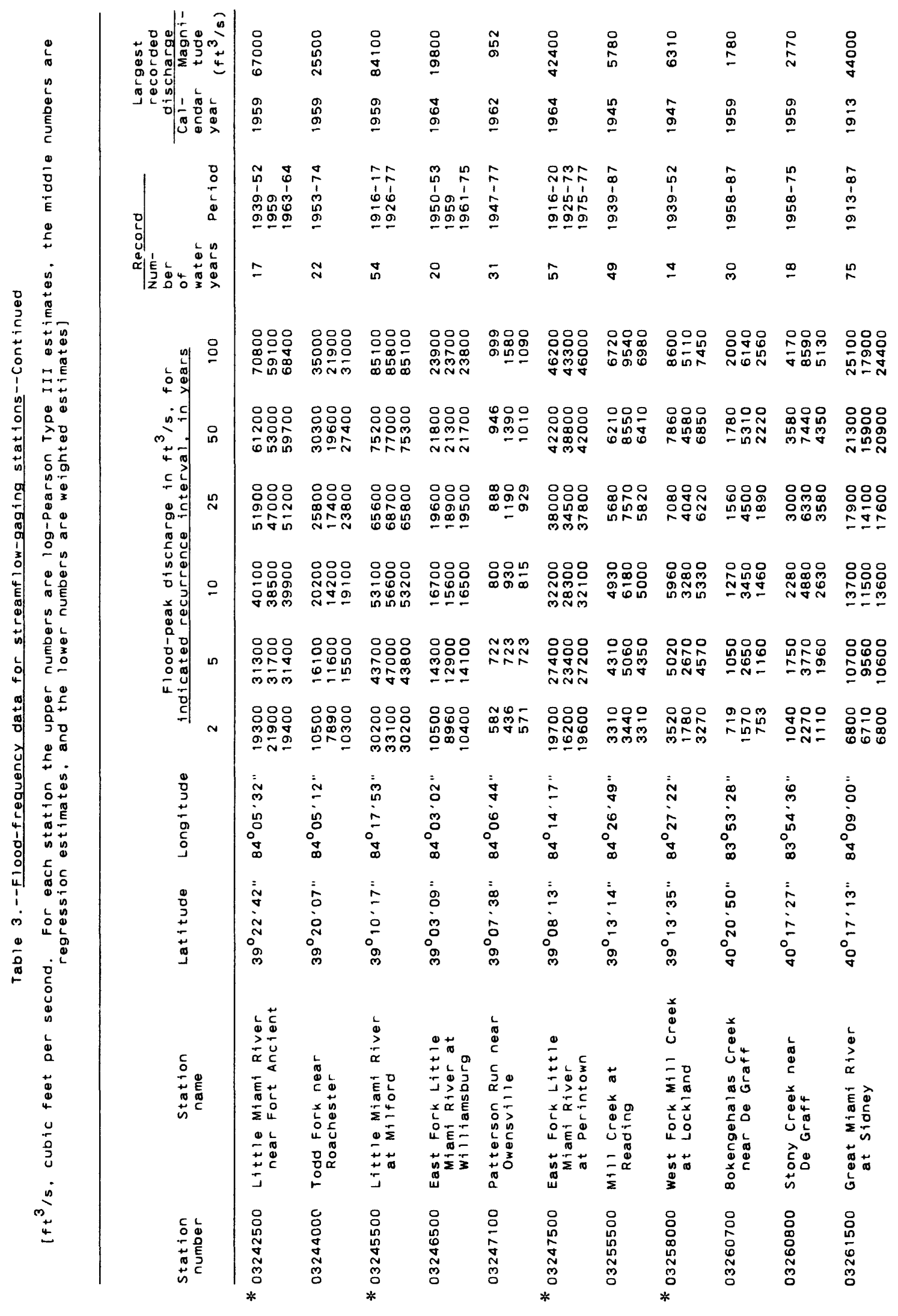




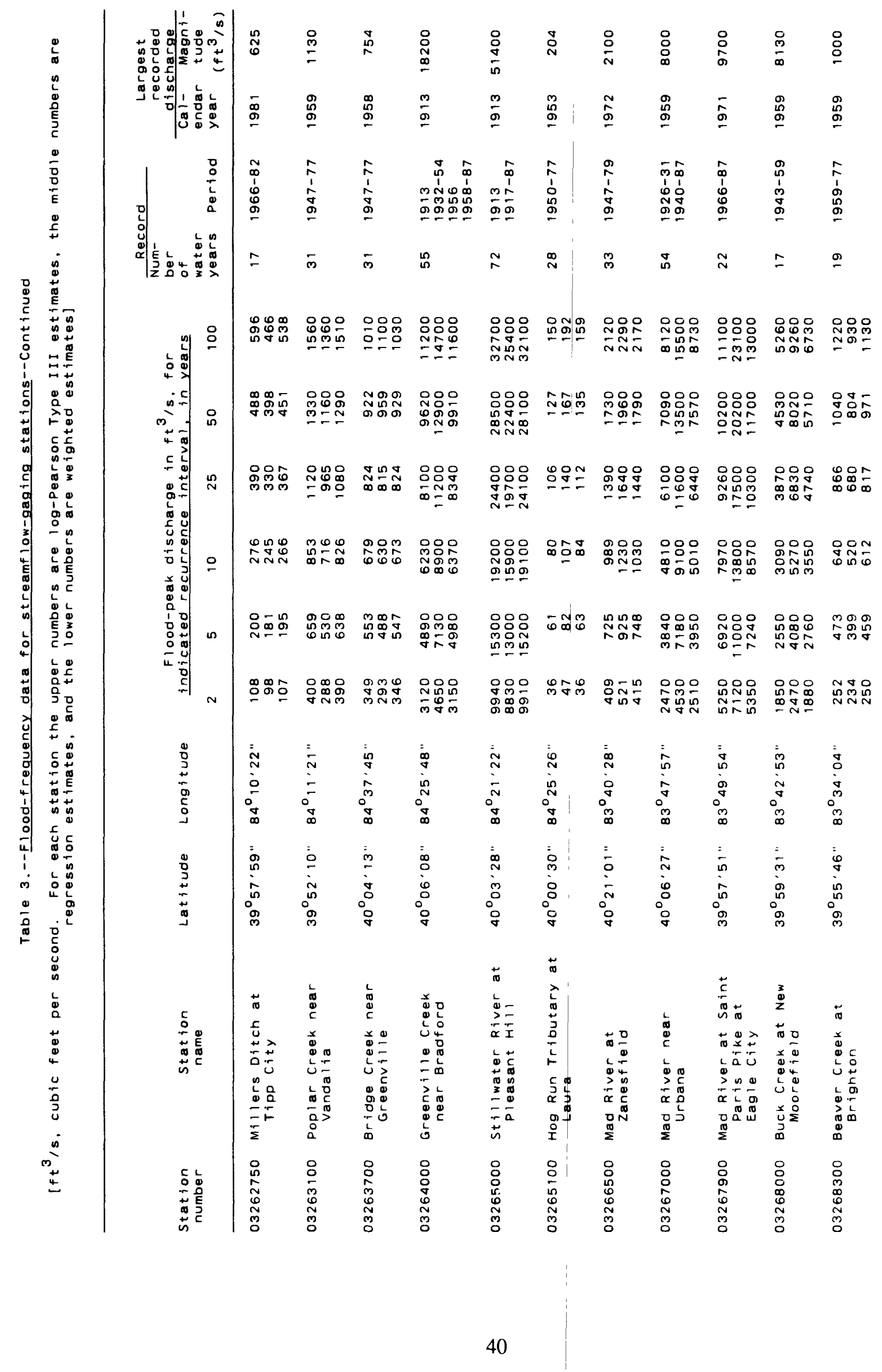




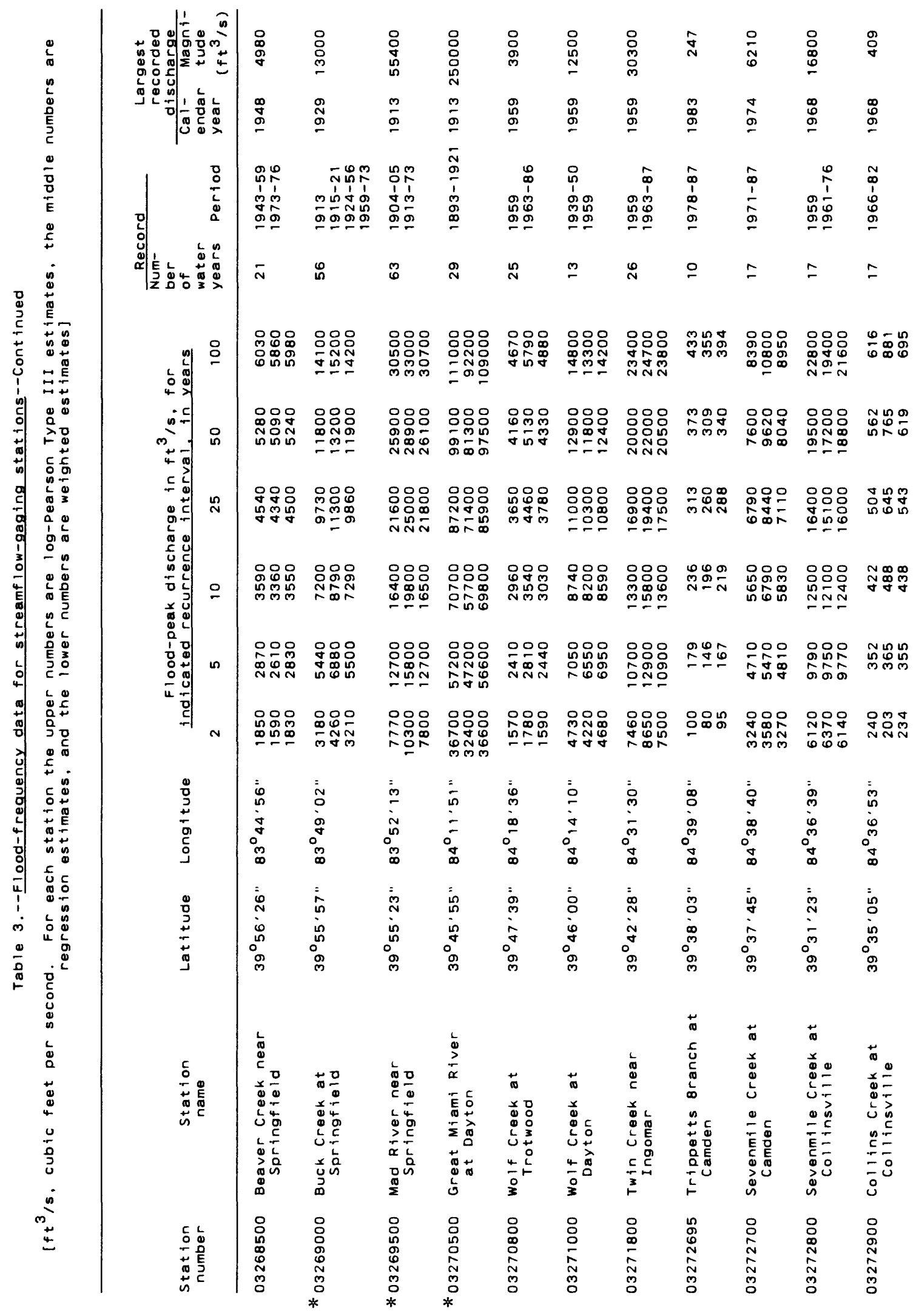




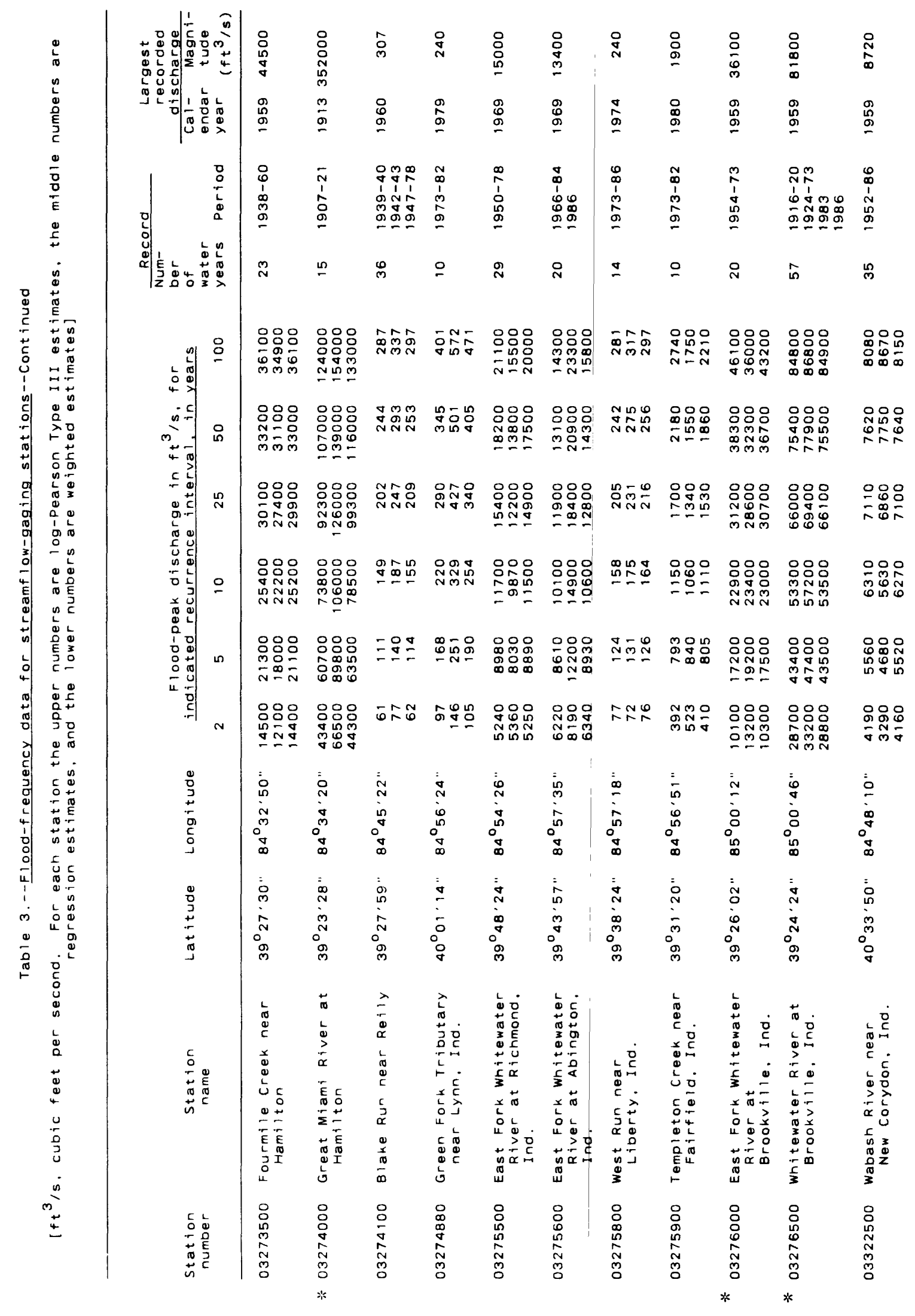




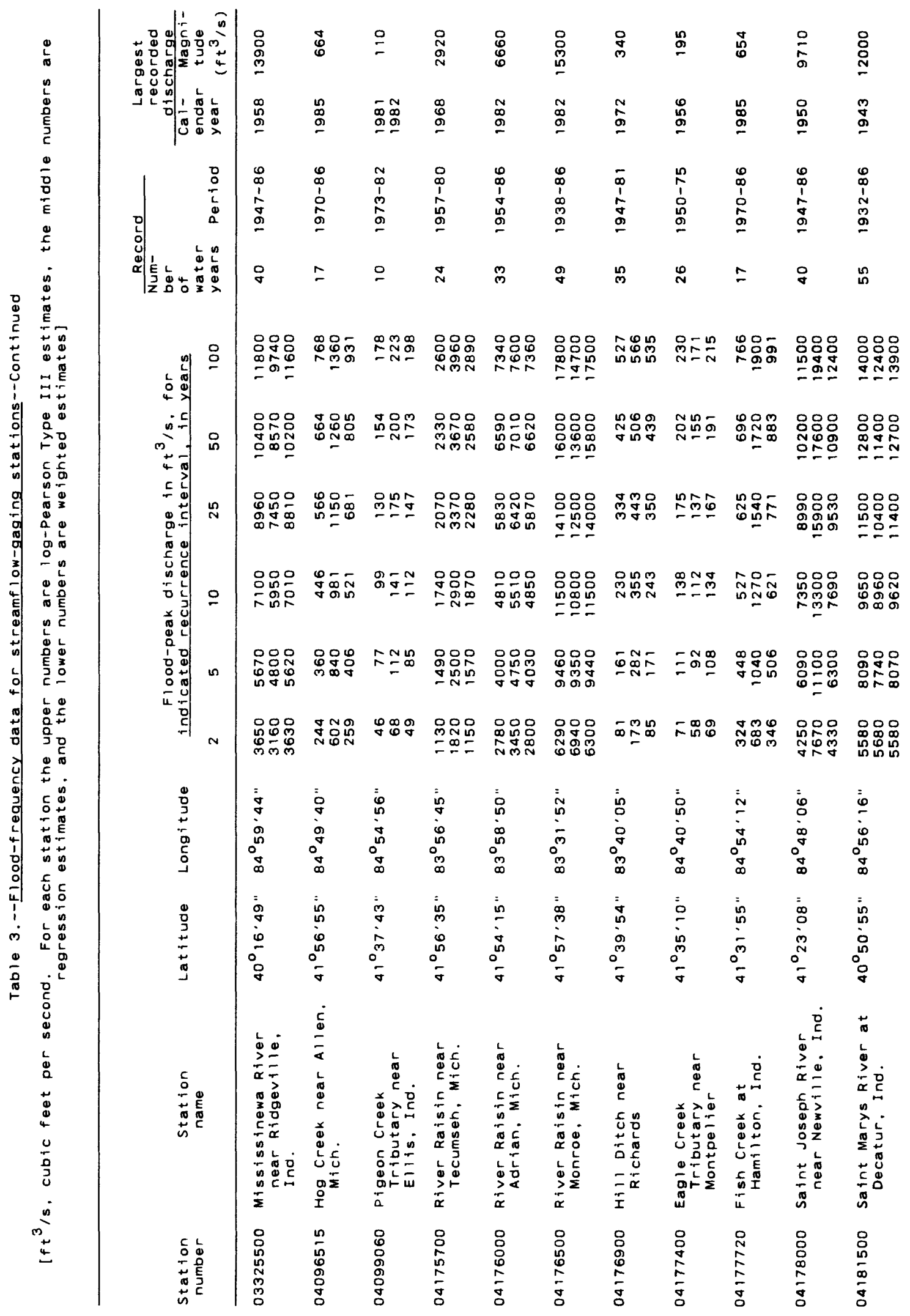




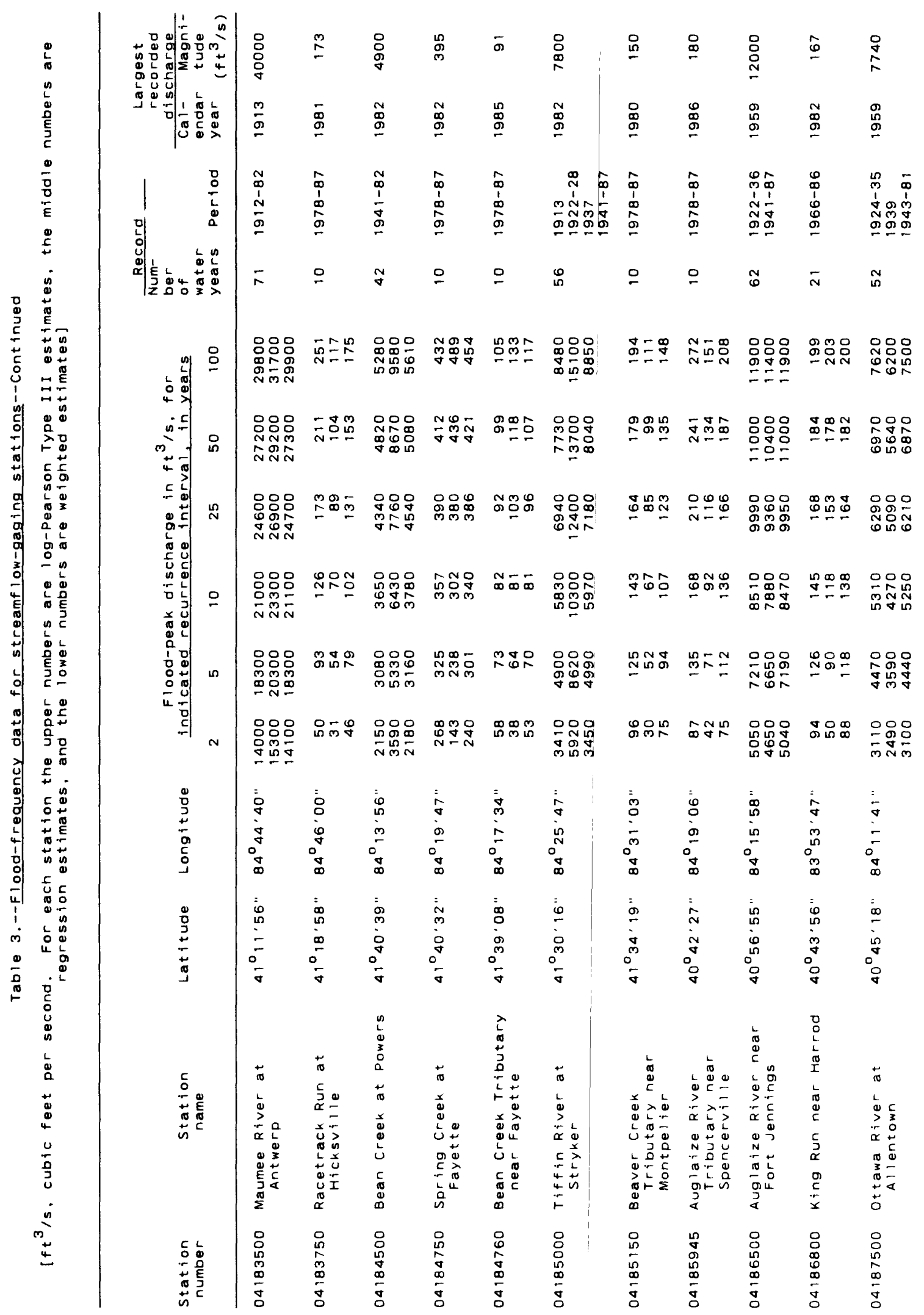




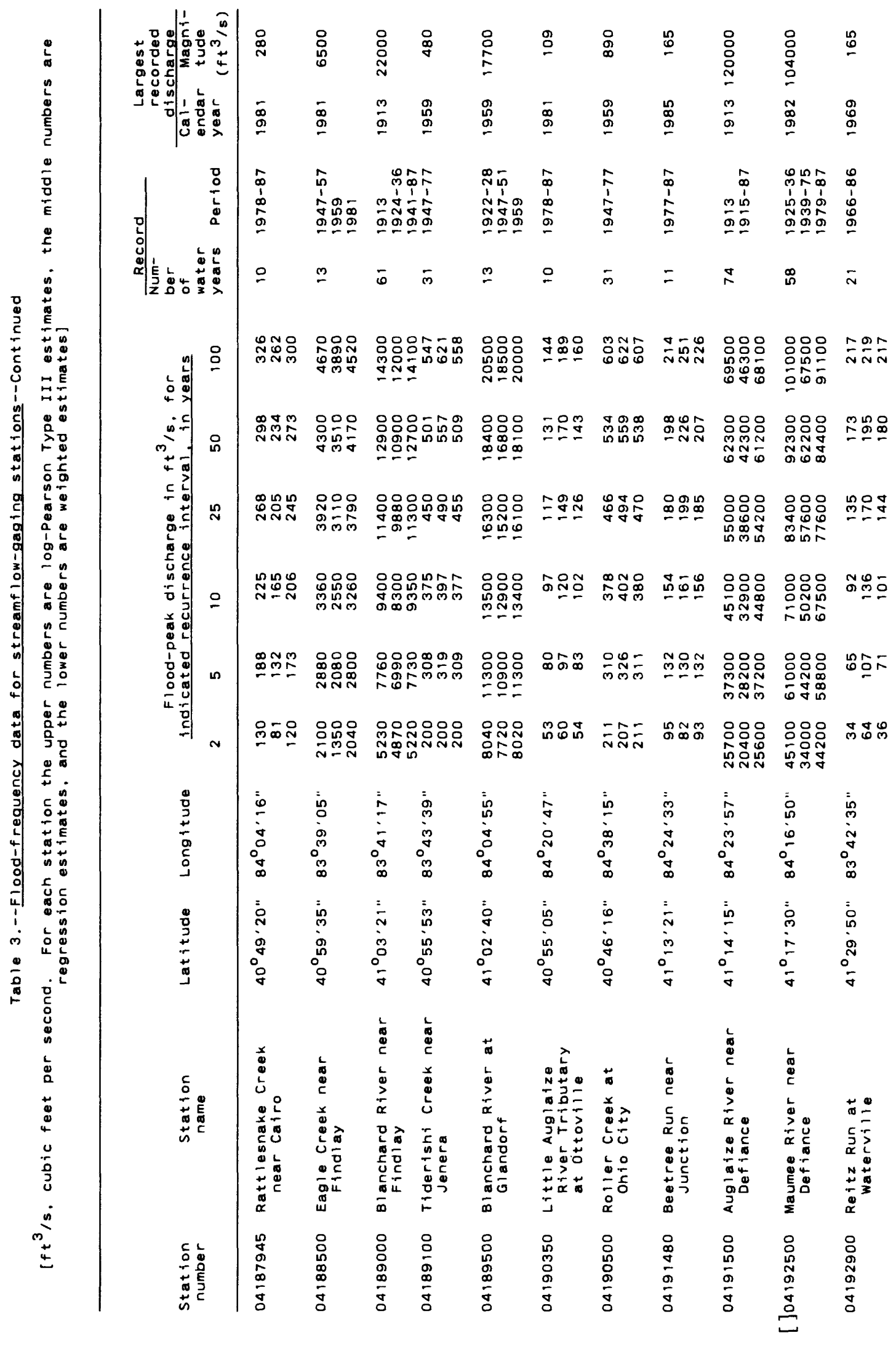




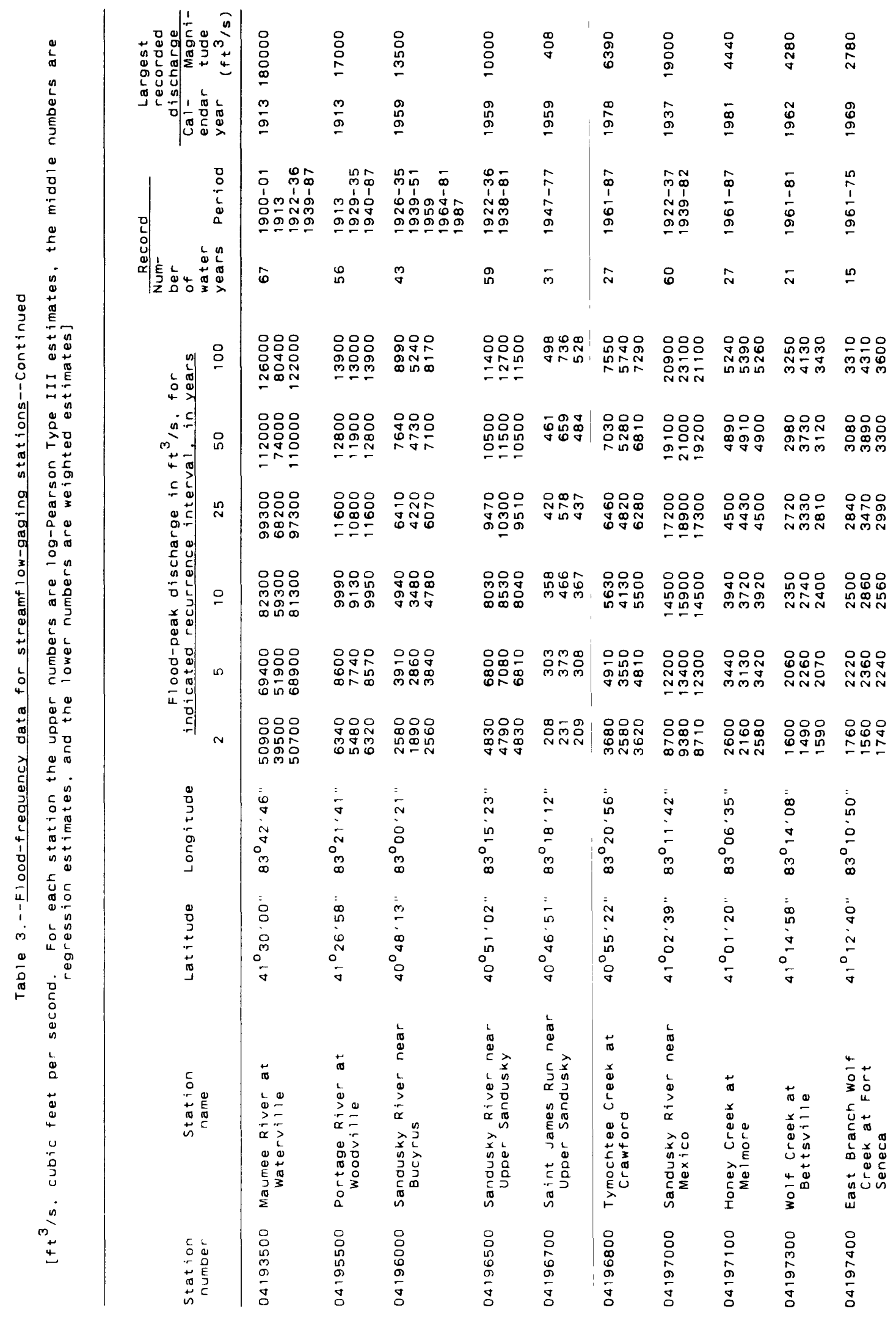




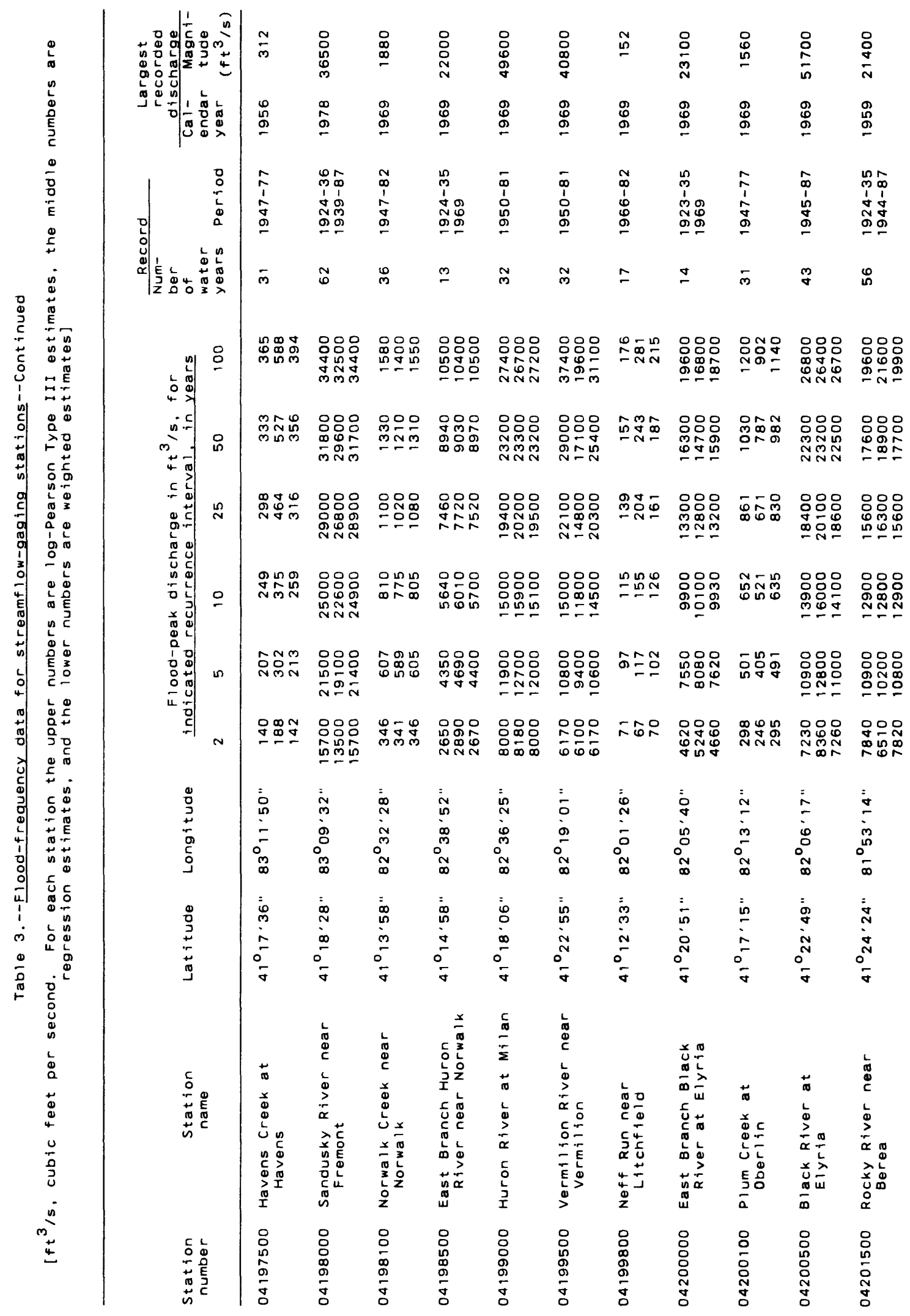




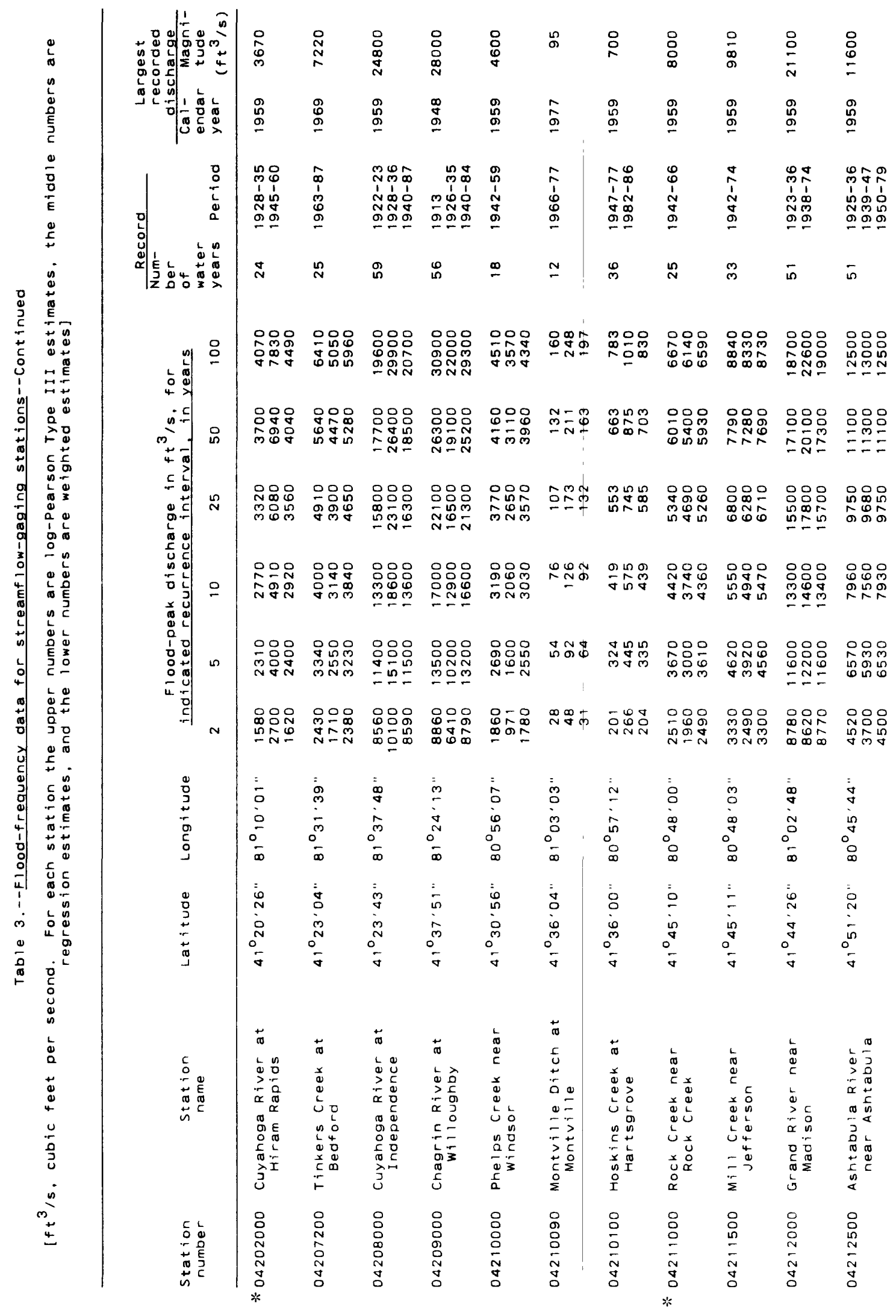




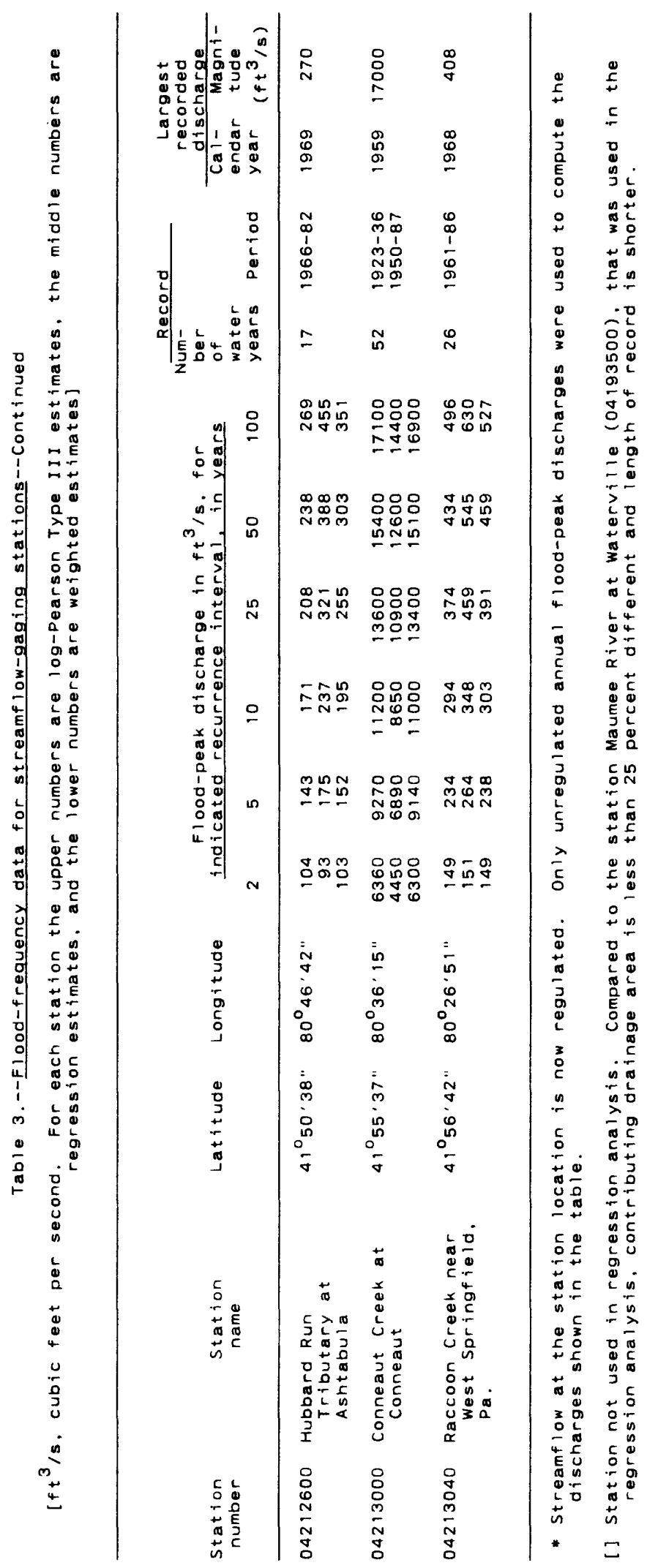




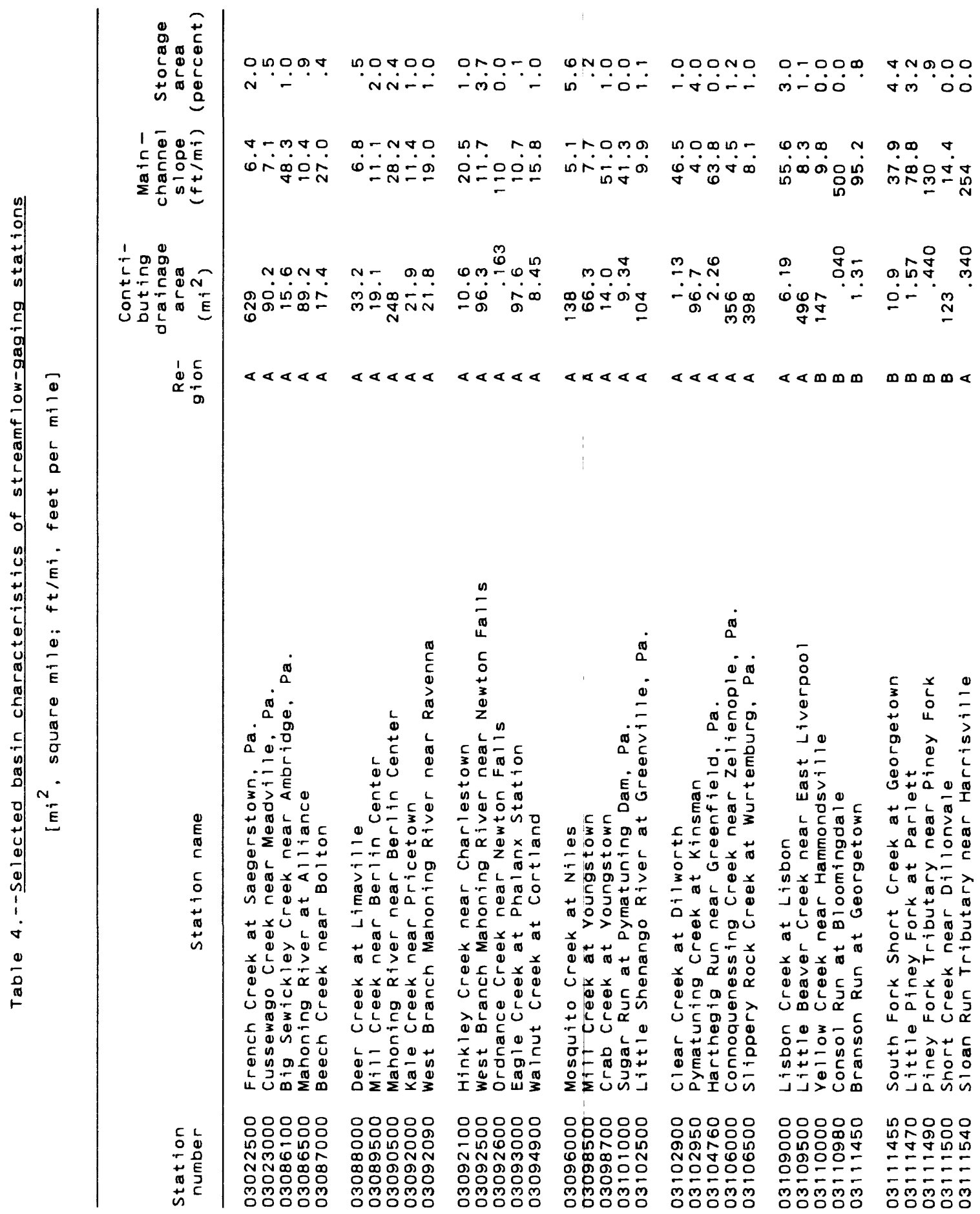




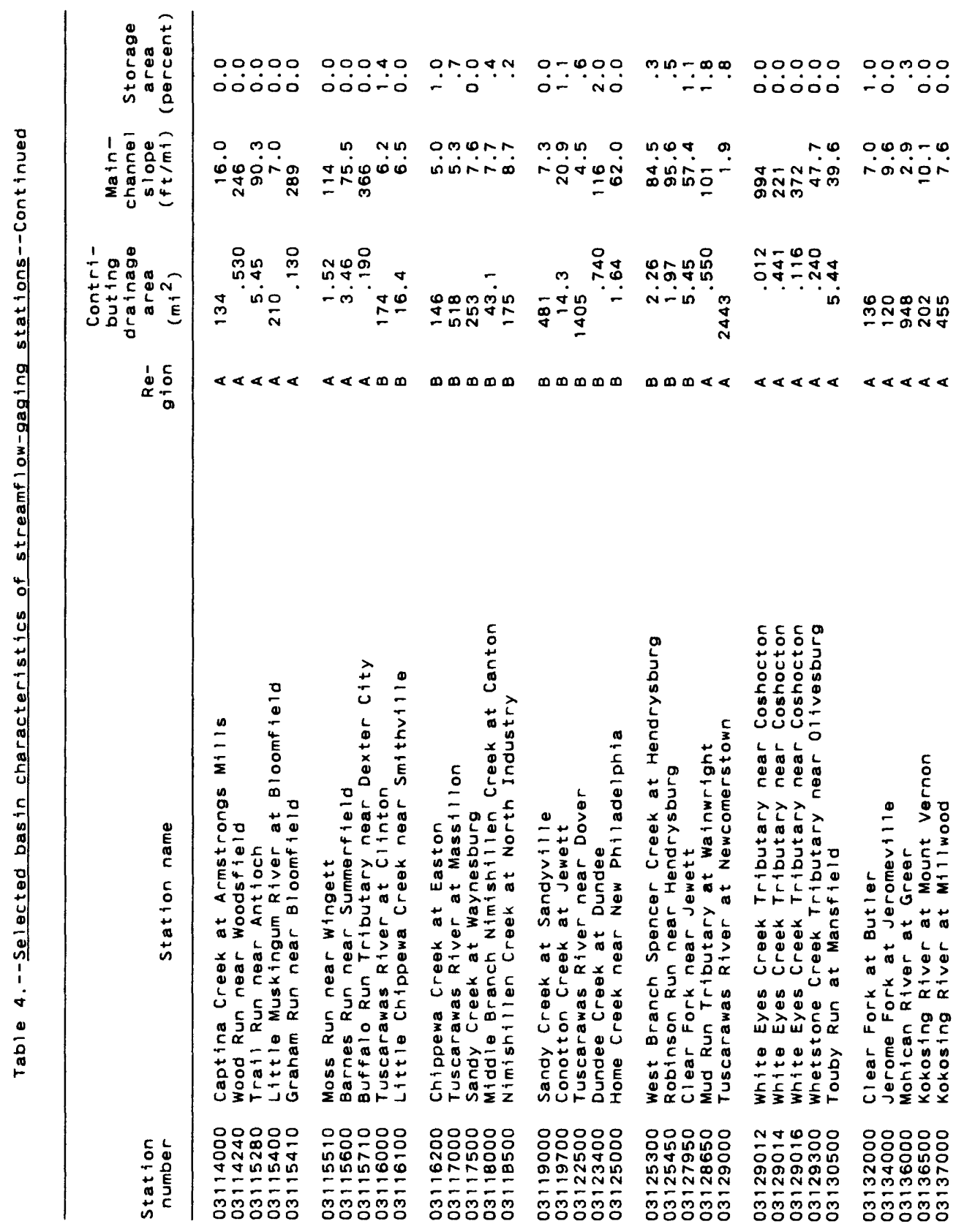




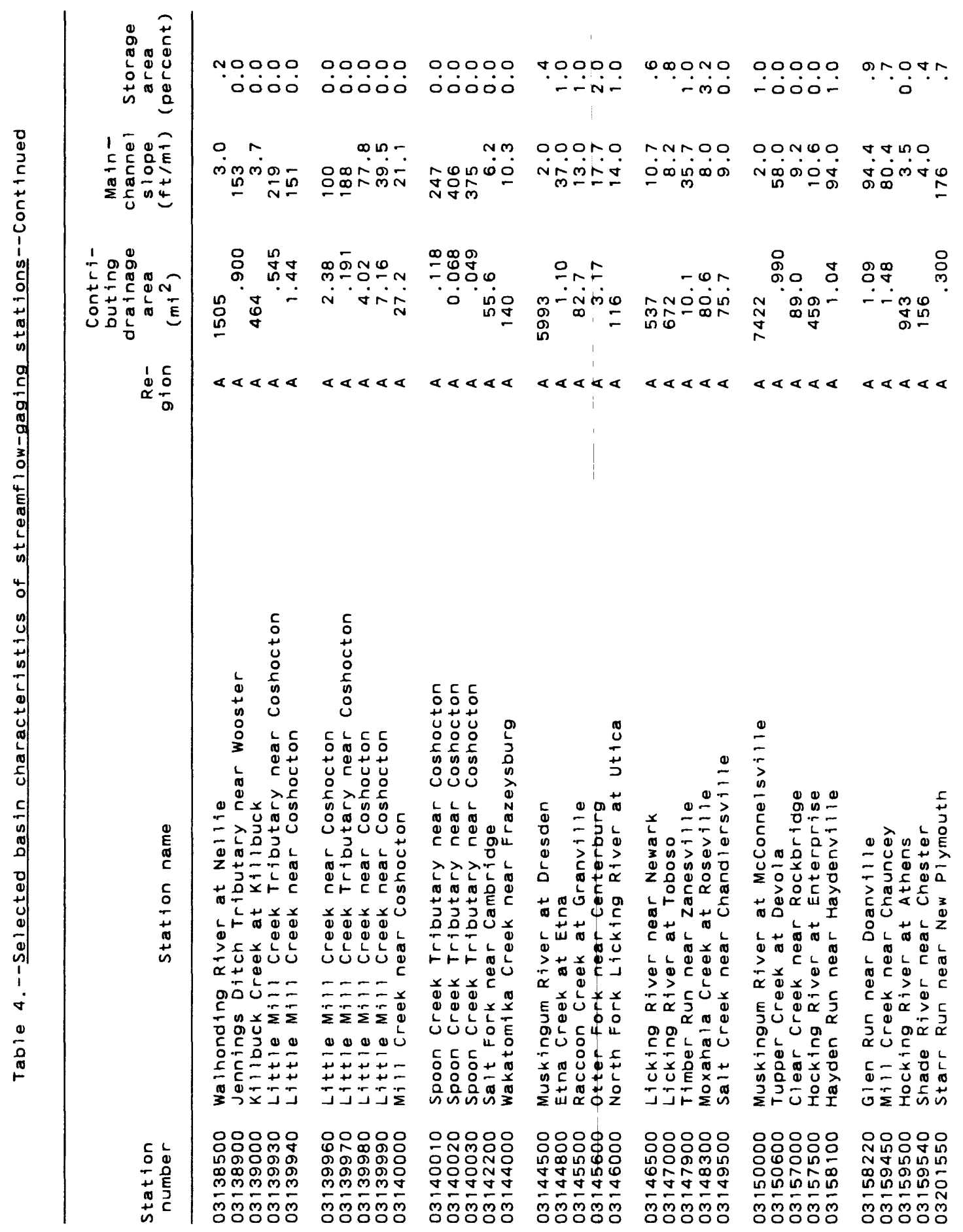




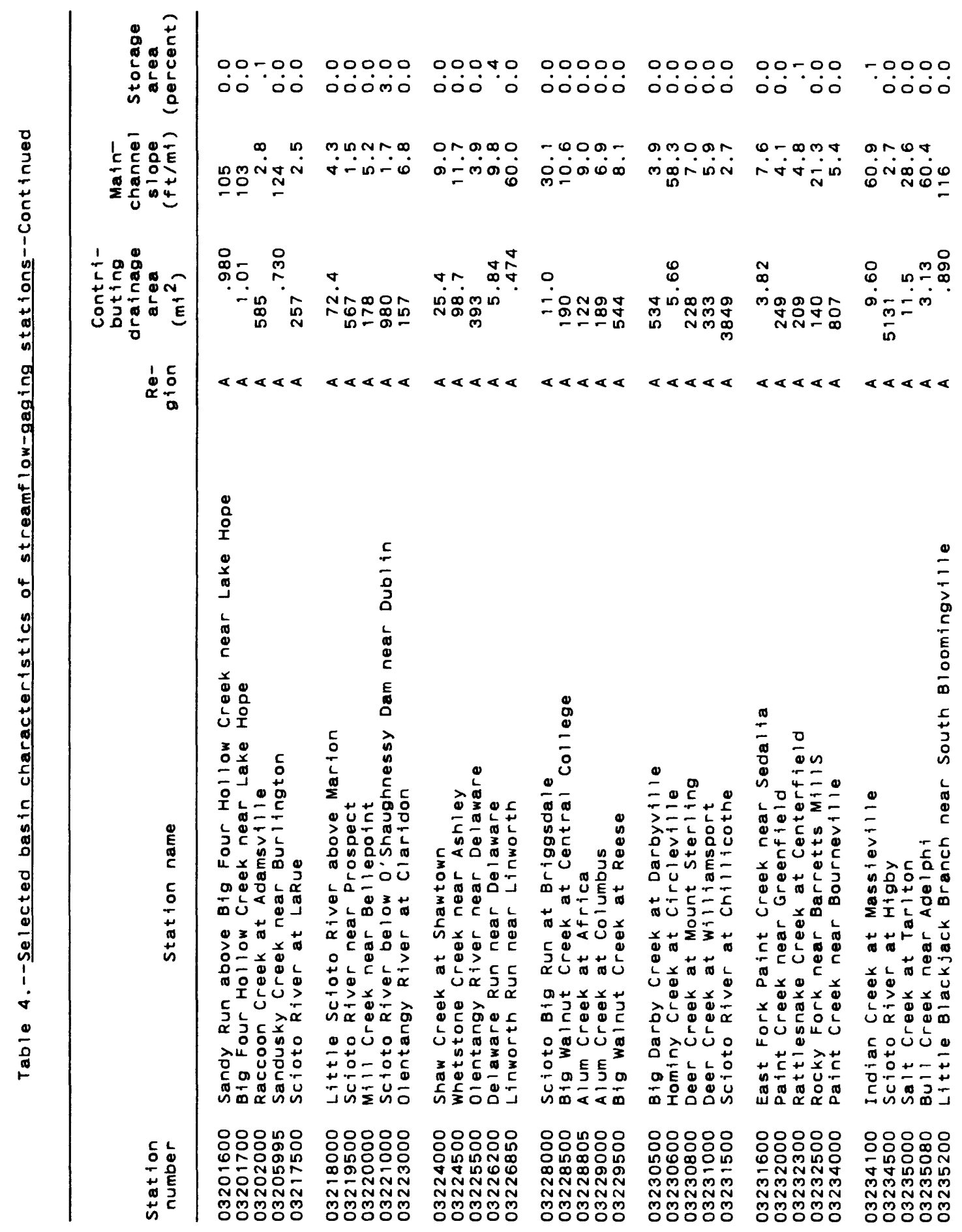




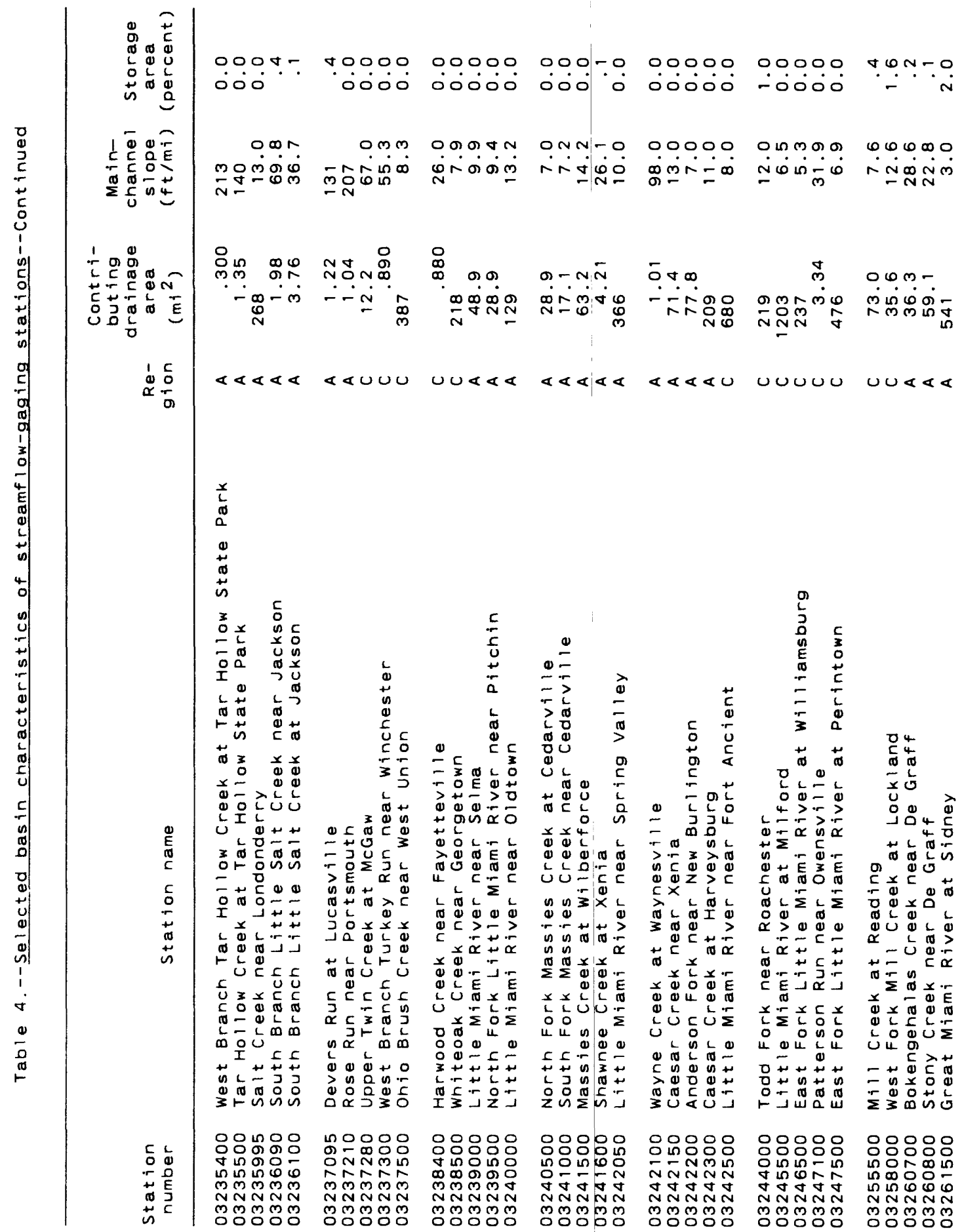




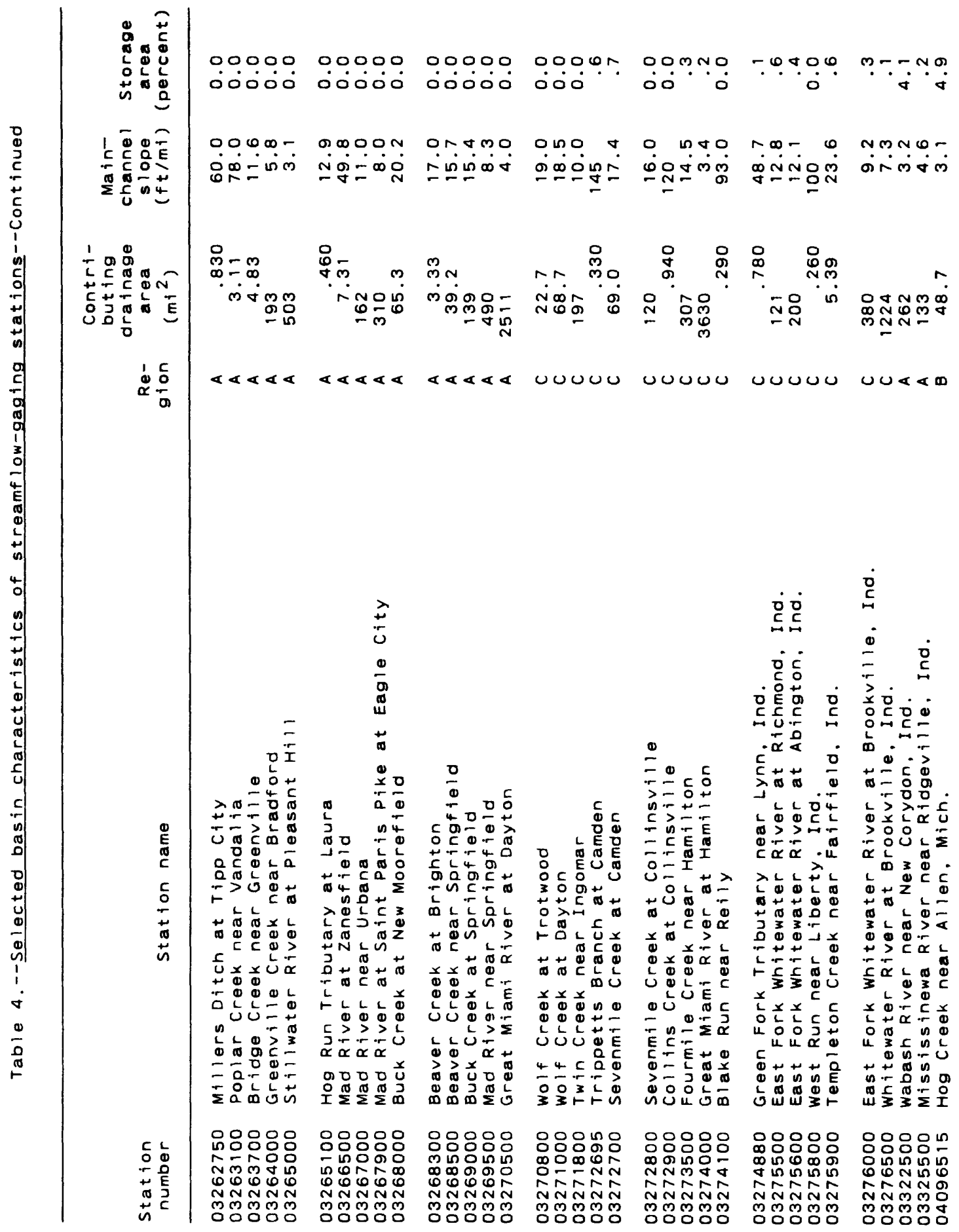




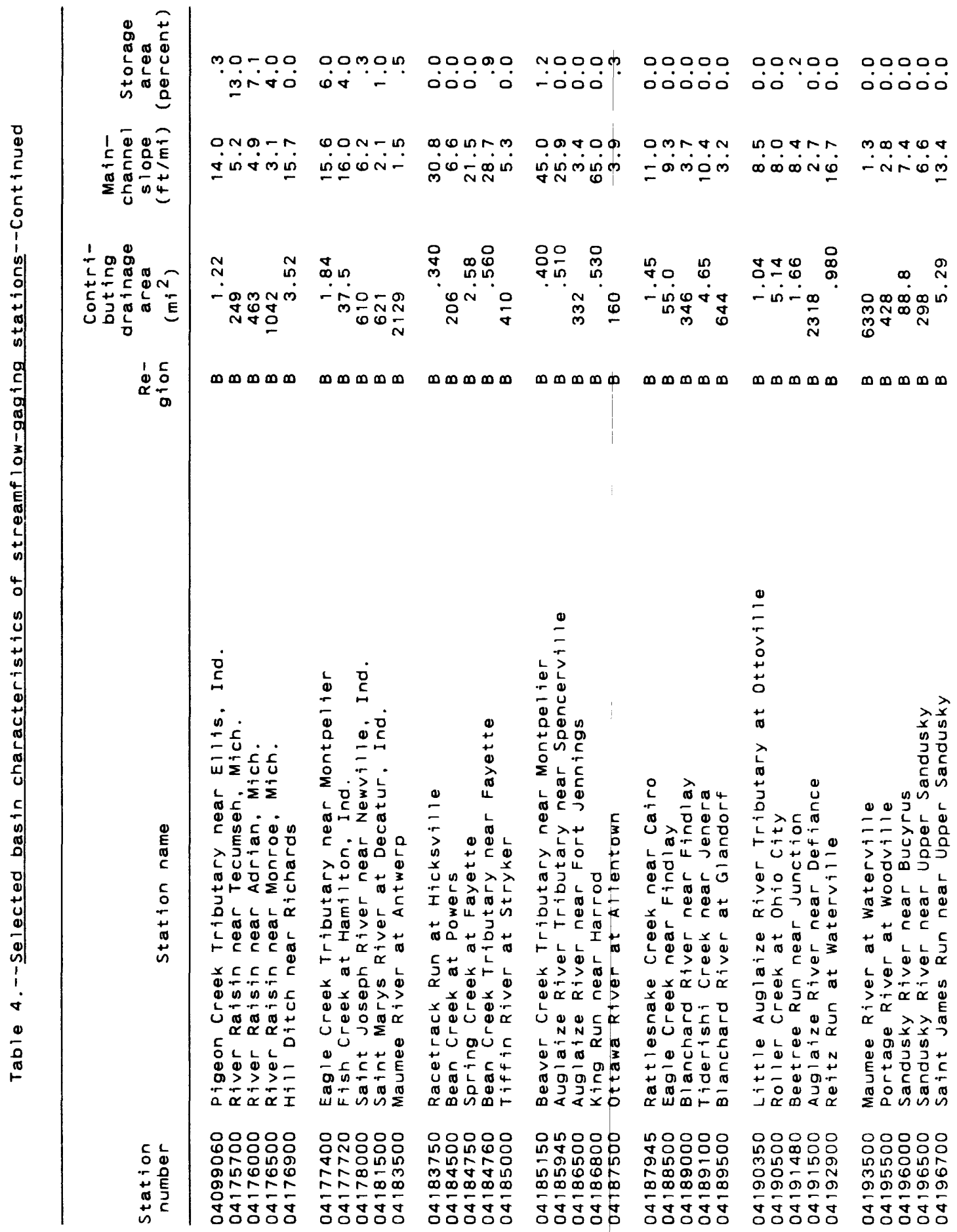




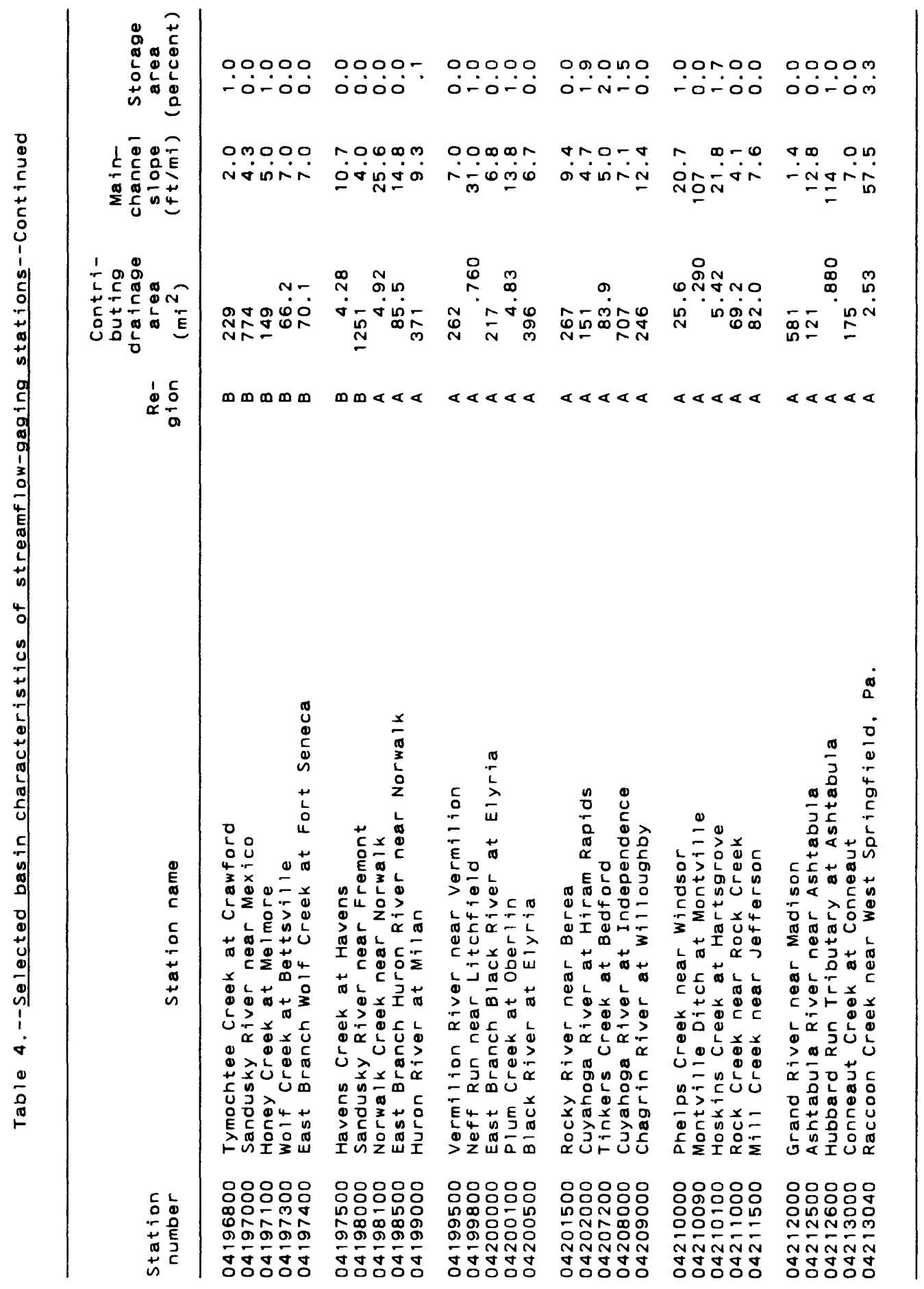




\section{APPENDIX A}

\section{Statistical Techniques for Determining Confidence Intervals and Testing for Extrapolation}

This appendix provides an outline and example of the steps that must be followed to determine confidence intervals for the true $t$-year peak discharge and perform a more rigorous test for extrapolation than is covered in the body of the report.

Steps for Determining Confidence Intervals and Testing for Extrapolation

(1) Compute the regression estimate of the at-site population standard deviation:

$$
\hat{\sigma}=\exp [\ln (\hat{\mathrm{s}})]
$$

where $\ln (\hat{\mathrm{s}})=-1.564-0.076\left(\log _{10}(\mathrm{CONTDA})\right)+0.153\left(\log _{10}(\mathrm{SLOPE})\right)$,

$\hat{\sigma}$ is regression estimate of the at-site population standard deviation, and

$\hat{\mathrm{S}}$ is regression estimate of the at-site sample standard deviation.

(2) Compute the estimated model error variance for the site of interest:

$$
\hat{\gamma}^{2}=\hat{\gamma}_{\mathrm{m}}^{2}+2 \hat{p}_{\mu \sigma} \mathrm{k} \hat{\Delta} \hat{\gamma}_{\mathrm{m}}+\mathrm{k}^{2} \hat{\Delta}^{2}
$$

where $\hat{\Delta}=\left[\hat{\sigma}^{2}\left(\exp \left(\hat{\gamma}_{s}^{2}\right)-1\right)\right] .5$,

$\hat{\gamma}^{2}$ is estimated model error variance for the regression of peak discharge on basin characteristics at the site of interest, 
$\hat{\gamma}_{\mathrm{m}}^{2}$ is estimated model error variance for the regression of sample mean on basin characteristics (in this analysis, $\hat{\gamma}_{\mathrm{m}}^{2}$ has been determined to have the numerical value $2.867 \times 10^{-2}$ ),

$\hat{\rho}_{\mu \sigma}$ is estimated correlation between the errors in the regressions for the mean and standard deviation (in this analysis, $\hat{\rho}_{\mu \sigma}$ has been determined to have the numerical values shown in table 5 for the tabulated recurrence intervals),

$\mathrm{k}$ is Pearson Type III frequency factor for the desired recurrence interval and skewness (the numerical values of $\mathrm{k}$ can be determined from tables published by Interagency Advisory Committee on Water Data, 1982), and

$\hat{\gamma}_{\mathrm{s}}^{2}$ is estimated model error variance for the regression of $\ln (\mathrm{s})$ on basin characteristics (in this analysis, $\hat{\gamma}_{\mathrm{s}}^{2}$ has been determined to have the numerical value $4.324 \times 10^{-2}$ ).

(3) Compute the estimated sampling error variance for the site of interest:

$$
\hat{\Sigma}=\mathbf{x} \mathbf{U} \mathbf{x}^{\mathrm{T}}
$$

where $\hat{\Sigma}$ is estimated sampling error variance for the site of interest,

$\mathbf{x}$ is a row vector of basin characteristics for the site of interest (table 6), and

$\mathbf{U}$ is the variance-covariance matrix, which was determined as follows: 


$$
\mathbf{U}=\left(\mathbf{X}^{\mathbf{T}} \hat{\mathbf{\Psi}}-1 \mathbf{X}\right)^{-1},
$$

where $\mathbf{X}$ is an $\mathrm{n}$ by $\mathrm{p}$ matrix of $\mathrm{p}-1$ basin characteristics augmented on the left by a column of ones,

$\hat{\Psi}$ is the $\mathrm{n}$ by $\mathrm{n}$ GLS estimate of the covariance matrix, and

$\mathrm{n}$ is number of observations in the regression data set.

(4) Test for extrapolation:

If $\hat{\Sigma}$ is greater than $\Sigma_{\max }$, then an estimate at the site of interest would constitute an extrapolation and consequently may suffer in accuracy. $\Sigma_{\max }$ is the maximum sampling error observed in the regression for the t-year peak discharge (table 5).

(5) Compute the regression estimate of the t-year peak discharge for the site of interest.

The regression equation for the desired region and recurrence interval should be selected from table 1 in the main body of the report.

(6) Compute the estimated variance of prediction at the site of interest:

where $\hat{V}_{p}$, the estimated variance of prediction at the site of interest, is defined as--

$$
\hat{\mathrm{V}}_{\mathrm{p}}=\hat{\gamma}^{2}+\hat{\Sigma}
$$


(7) Compute the $100(1-\alpha)$ percent confidence interval for the true t-year peak discharge:

$$
\begin{aligned}
& \hat{y}_{\mathrm{u}}=(C) \hat{y} \\
& \hat{y}_{1}=\left(\frac{1}{\mathrm{C}}\right) \hat{\mathrm{y}} \\
& \mathrm{C}=10^{[\mathrm{t}}(\alpha / 2, \mathrm{n}-\mathrm{p})\left(\hat{\mathrm{v}}_{\mathrm{p}} \cdot \mathrm{s}^{.5},\right.
\end{aligned}
$$

where $\hat{y}_{\mathrm{u}}$ is upper confidence limit,

$$
\begin{gathered}
\hat{\mathrm{y}}_{1} \text { is lower confidence limit, and } \\
\mathrm{t}_{(\alpha / 2, \mathrm{n}-\mathrm{p})} \begin{array}{l}
\text { is critical value of the Student's } \mathrm{t} \text { distribution for } \mathrm{n}-\mathrm{p} \text { degrees of } \\
\text { freedom. }
\end{array}
\end{gathered}
$$

\section{Example}

Estimate the 100-year peak discharge and the 90-percent confidence interval for an ungaged site with the following basin characteristics:

$\begin{array}{ll}\text { Contributing drainage area (CONTDA) } & =123 \mathrm{mi}^{2} \\ \text { Main-channel slope (SLOPE) } & =14.4 \mathrm{ft} / \mathrm{mi} \\ \text { Storage area (STORAGE) } & =0.0 \text { percent } \\ \text { Region } & =\mathrm{B}\end{array}$


(1) Compute $\hat{\sigma}$ :

$$
\begin{aligned}
\ln (\hat{\mathbf{s}}) & =-1.564-0.076\left(\log _{10}(\mathrm{CONTDA})\right)+0.153\left(\log _{10}(\mathrm{SLOPE})\right) \\
& =-1.564-0.076\left(\log _{10}(123)\right)+0.153\left(\log _{10}(14.4)\right) \\
& =-1.546 \\
\hat{\sigma} & =\exp [\ln (\hat{\mathrm{s}})] \\
& =\exp [-1.546] \\
& =0.213 .
\end{aligned}
$$

(2) Compute $\hat{\gamma}^{2}$ :

$$
\begin{aligned}
& \hat{\Delta}=\left[\hat{\sigma}^{2}\left(\exp \left(\hat{\gamma}_{\mathrm{s}}^{2}\right)-1\right)\right] .5 \\
& =\left[(0.213)^{2}\left(\exp \left(4.324 \times 10^{-2}\right)-1\right)\right]^{.5} \\
& =4.48 \times 10^{-2} \text {. } \\
& \hat{\gamma}^{2}=\hat{\gamma}_{\mathrm{m}}^{2}+2 \hat{\rho}_{\mu \sigma} \mathrm{k} \hat{\Delta} \hat{\gamma}_{\mathrm{m}}+\mathrm{k}^{2} \hat{\Delta}^{2} \\
& =2.867 \times 10^{-2}+(2)(-0.52)(2.326)\left(4.48 \times 10^{-2}\right)\left(2.867 \times 10^{-2}\right)^{0.5}+(2.326)^{2}\left(4.48 \times 10^{-2}\right)^{2} \\
& =2.118 \times 10^{-2}
\end{aligned}
$$

where $\mathrm{k}$ is determined from a table of published values and is based on a 100 -year recurrence interval and 0 skew coefficient. 
(3) Compute $\hat{\Sigma}$ :

$$
\begin{aligned}
& \hat{\Sigma}=\mathbf{x} \mathbf{U} \mathbf{x}^{\mathrm{T}} \\
& =1.280 \times 10^{-3} \text {, } \\
& \text { where } x=\left[\begin{array}{llllll}
x(1) & x(2) & x(3) & x(4) & x(5) & x(6)
\end{array}\right] \\
& =\left[1 \log _{10}(\mathrm{CONTDA}) \log _{10}(\mathrm{SLOPE}) \log _{10}(\mathrm{STORAGE}+1) \times(5) \times(6)\right]
\end{aligned}
$$

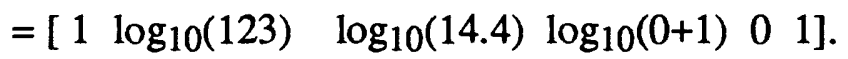

$$
\begin{aligned}
& \mathbf{U}=\text { the variance-covariance matrix for the } 100 \text {-year recurrence interval from }
\end{aligned}
$$

Note that the form of the $\mathbf{x}$-vector for Region B is obtained from table 6.

(4) Test for extrapolation:

$\hat{\Sigma}_{\max }=3.881 \times 10^{-3}$ (from table 5 for the 100 -year recurrence interval).

Because $\hat{\Sigma}$ is not greater than $\hat{\Sigma}$ max , the estimate will not be an extrapolation.

(5) Compute the regression estimate of the 100-year peak discharge. The equation for the 100 -year peak discharge for region $B$ is:

$$
\begin{aligned}
\hat{y} & =99.7(\text { CONTDA })^{0.756}(\text { SLOPE })^{0.285}(\text { STORAGE }+1)^{-0.363} \\
& =99.7(123)^{0.756}(14.4)^{0.285}(0+1)^{-.0 .363} \\
& =8,110 \text { cubic feet per second } .
\end{aligned}
$$


(6) Compute the estimated variance of prediction:

$$
\begin{aligned}
\hat{\mathrm{V}}_{\mathrm{p}} & =\hat{\gamma}^{2}+\hat{\Sigma} \\
& =2.118 \times 10^{-2}+1.280 \times 10^{-3} \\
& =2.246 \times 10^{-2} .
\end{aligned}
$$

(7) Compute the 90-percent confidence interval:

$$
\begin{aligned}
\mathrm{C} & =10_{\alpha / 2, \mathrm{n}-\mathrm{p}}^{[\mathrm{t}}\left(\hat{\mathrm{v}}_{\mathrm{p}}\right)^{0.5]} \\
& =10^{\left[(1.65)\left(2.246 \times 10^{-2}\right)^{0.5}\right]} \\
& =1.767 \\
\hat{\mathrm{y}}_{\mathrm{u}} & =(\mathrm{C}) \hat{\mathrm{y}} \\
& =1.767(8110) \\
& =14,300 \text { cubic feet per second. } \\
\hat{y}_{1} & =\left(\frac{1}{\mathrm{C}}\right) \hat{\mathrm{y}} \\
& =\frac{1}{1.767}(8110) \\
& =4,590 \text { cubic feet per second. }
\end{aligned}
$$

The 90-percent confidence interval for $\hat{y}=8,110$ is $(14,300,4,590)$. 
Table 5.- $\hat{\rho}_{\mu \sigma}$ and $\hat{\Sigma}_{\text {max }}$ values, by recurrence interval

\begin{tabular}{ccl}
\hline $\begin{array}{c}\text { Recurrence } \\
\text { interval } \\
\text { (years) }\end{array}$ & $\hat{\rho}_{\mu \sigma}$ & $\hat{\Sigma}_{\max }$ \\
& & \\
2 & & \\
5 & -1.0 & $3.519 \times 10^{-3}$ \\
10 & -.79 & $2.719 \times 10^{-3}$ \\
25 & -.65 & $2.820 \times 10^{-3}$ \\
50 & -.58 & $3.126 \times 10^{-3}$ \\
100 & -.55 & $3.489 \times 10^{-3}$ \\
& -.52 & $3.881 \times 10^{-3}$ \\
\hline
\end{tabular}

Table 6.-Regions and $x$-vectors

[The row vector is augmented on the left by a 1 and on the right by two numbers which depend on the region in which the site of interest is located]

\begin{tabular}{ccccccc}
\hline & \multicolumn{7}{c}{$\mathbf{x}$-vector } \\
\cline { 2 - 7 } Region & $\mathrm{x}(1)$ & $\mathrm{x}(2)$ & $\mathrm{x}(3)$ & $\mathrm{x}(4)$ & $\mathrm{x}(5)$ & $\mathrm{x}(6)$ \\
\hline $\mathrm{A}$ & 1 & $\log _{10}$ (CONTDA) & $\log _{10}$ (SLOPE) & $\log _{10}$ (STORAGE +1$)$ & 0 & 0 \\
$\mathrm{~B}$ & 1 & $\log _{10}$ (CONTDA) & $\log _{10}$ (SLOPE) & $\log _{10}$ (STORAGE+1) & 0 & 1 \\
$\mathrm{C}$ & 1 & $\log _{10}$ (CONTDA) & $\log _{10}$ (SLOPE) & $\log _{10}$ (STORAGE+1) & 1 & 0 \\
\hline
\end{tabular}




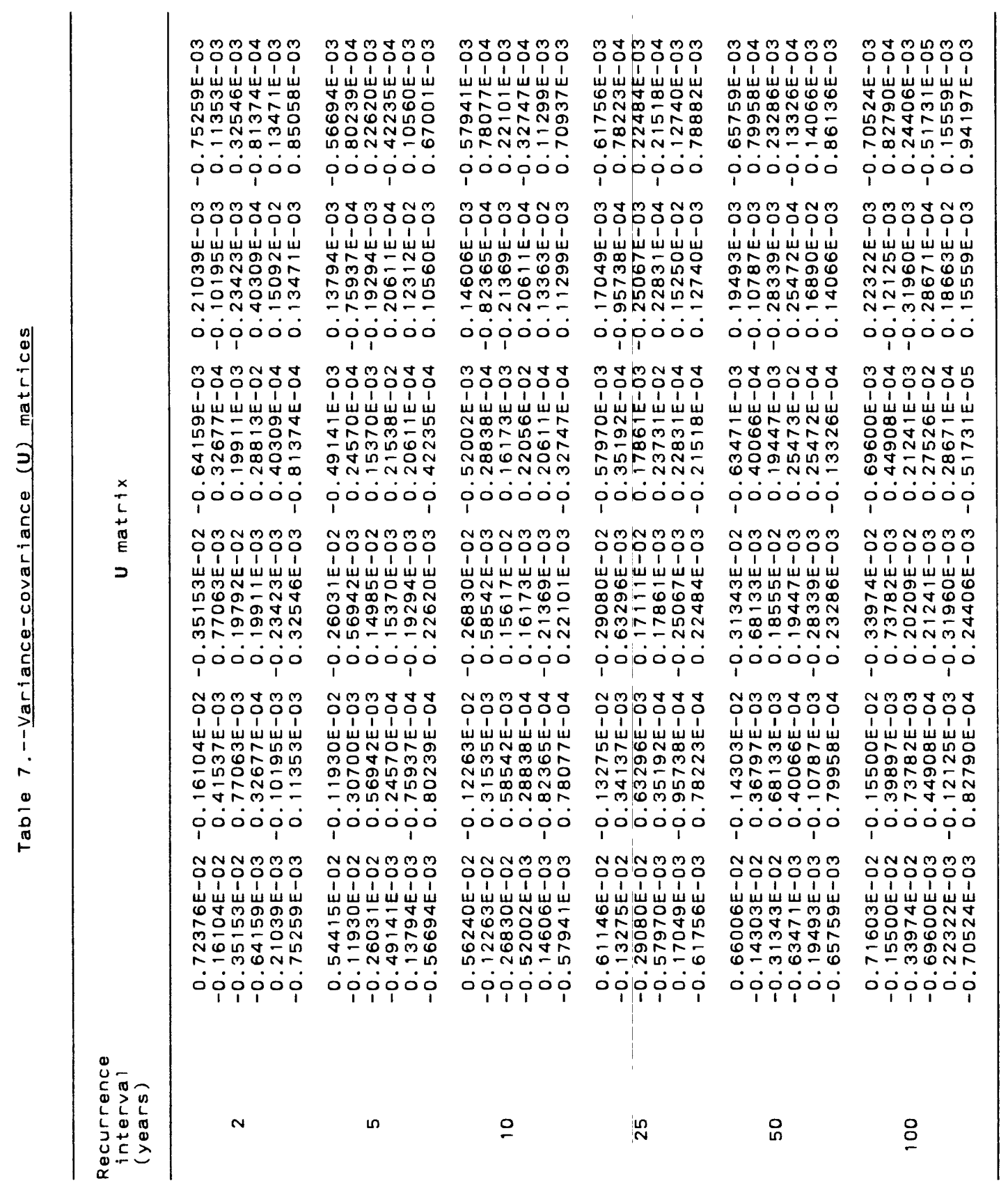




\section{APPENDIX B}

\section{Independent Variables Tested as Potential Regressor Variables}

The following independent variables, which provide measures of basin characteristics, were tested as potential regressor variables. These variables were determined from U.S. Geological Survey 7.5-minute topographic quadrangle maps unless stated otherwise.

Contributing drainage area (in square miles). - the area, measured in a horizontal plane, that contributes surface runoff to a specified location on a stream. This area may be located inside or outside of the natural topographic divides of the basin.

Main-channel slope (in feet per mile).-computed as the difference in elevation at points 10 and 85 percent of the distance along the main channel from a specified location on the channel to the topographic divide, divided by the channel distance between the two points.

Main-channel length (in miles).- determined by measuring the distance along the main channel from a specified location to the topographic divide.

Mean basin elevation (in feet above sea level).- average of 20 to 80 groundpoint elevations evenly distributed throughout the basin.

Basin elevation index (in thousands of feet above sea level). - determined by averaging main-channel elevations at points 10 and 85 percent of the distance from a specified location on the main channel to the topographic divide.

Basin shape index.- a dimensionless number computed by dividing the square of the main-channel length by the contributing drainage area.

Storage area.- the percentage of the contributing drainage area occupied by lakes, ponds, and swamps as explicitly shown on U.S. Geological Survey 7.5-minute topographic quadrangle maps. For the regression analysis, 1 was added to the storage-area percentage.

Forested area.- the percentage of the contributing drainage area occupied by forest cover. For the regression analysis, 1 was added to the forested-area percentage. 
Surface-mined area.- the percentage of the contributing drainage area occupied by disturbed earth resulting from surface mining. For the regression analysis, 1 was added to the surface-mined-area percentage.

Mean annual precipitation (in inches).-determined from Ohio Department of Natural Resources, Ohio Water Plan Inventory Report 13 (Ohio Division of Water, 1962). For the regression analysis, 27 was subtracted from mean annual precipitation to account for annual evapotranspiration.

24-hour, 2-year rainfall (in inches). - the 24-hour rainfall expected to be equalled or exceeded an average of one time in a 2-year period, determined from Weather Bureau Technical Paper no. 40 (U.S. Department of Commerce, 1961).

Mean minimum January temperature (in degrees Fahrenheit). - determined from Weather Bureau, Climatography of the United States, no. 60-33 (U.S. Department of Commerce, 1959). Mean minimum January temperature was subtracted from 32 for the regression analysis to represent the number of degrees below freezing. 